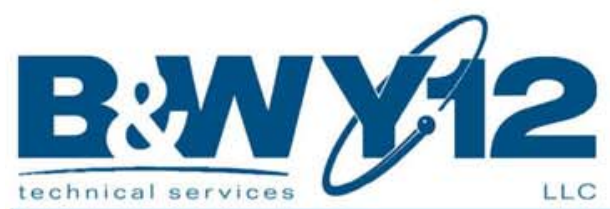

Y-12

NATIONAL SECURITY COMPLEX
Y-12 GROUNDWATER PROTECTION PROGRAM

EXTENT OF THE PRIMARY GROUNDWATER CONTAMINANTS

AT THE Y-12 NATIONAL SECURITY COMPLEX

December 2013

Prepared by

Elvado Environmental LLC

Under Subcontract No. 4300087609

for the

Environmental Compliance Department Environment, Safety, and Health Division Y-12 National Security Complex

Oak Ridge, Tennessee 37831

\section{Managed by}

Babcock \& Wilcox Technical Services Y-12, LLC

for the U.S. Department of Energy

Under Contract No. DE-AC05-00OR22800 


\section{DISCLAIMER}

This report was prepared as an account of work sponsored by an agency of the United States Government. Neither the United States Government nor any agency thereof, nor any of their employees, makes any warranty, express or implied, or assumes any legal liability or responsibility for the accuracy, completeness, or usefulness of any information, apparatus, product, or process disclosed, or represents that its use would not infringe privately owned rights. Reference herein to any specific commercial product, process, or service by trade name, trademark, manufacturer, or otherwise, does not necessarily constitute or imply its endorsement, recommendation, or favoring by the United States Government or any agency thereof. The views and opinions of authors expressed herein do not necessarily state or reflect those of the United States Government or any agency thereof. 


\title{
Y-12 GROUNDWATER PROTECTION PROGRAM EXTENT OF THE PRIMARY GROUNDWATER CONTAMINANTS AT THE Y-12 NATIONAL SECURITY COMPLEX
}

\author{
December 2013
}

\author{
Prepared by \\ Elvado Environmental LLC \\ Under Subcontract No. 4300087609
}

for the

Environmental Compliance Department Environment, Safety, and Health Division Y-12 National Security Complex

Oak Ridge, Tennessee 37831

\section{Managed by}

Babcock \& Wilcox Technical Services Y-12, LLC for the U.S. DEPARTMENT OF ENERGY under contract No. DE-AC05-00OR22800 


\section{CONTENTS}

2.0 GROUNDWATER CONTAMINANT PLUME DELINEATION …............................................

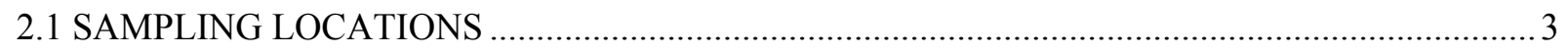

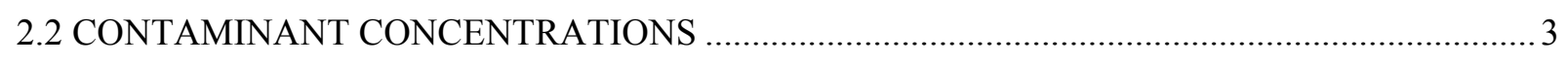

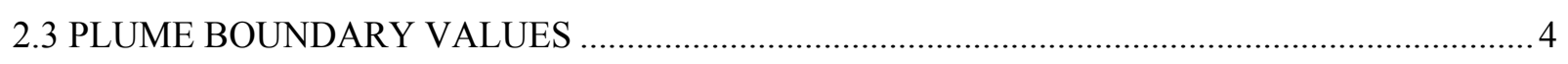

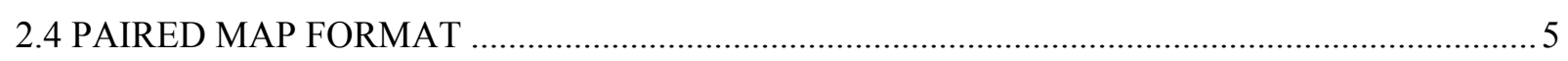

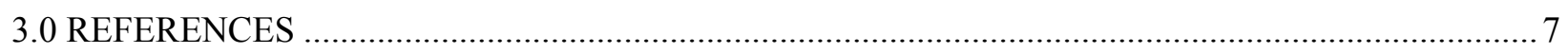

\section{APPENDIX A: DATA SUMMARY TABLES}

A.1 Data summary of mapped organic groundwater contaminants.................................................... A-1

A.2 Data summary of mapped inorganic and radiological groundwater contaminants........................ A-11

\section{APPENDIX B: CONTAMINANT PLUME MAPS}

B.1 Lateral extent of tetrachloroethene in groundwater at the Y-12 National Security Complex, West........

B.2 Lateral extent of tetrachloroethene in groundwater at the Y-12 National Security Complex, East

B.3 Lateral extent of trichloroethene in groundwater at the Y-12 National Security Complex, West........

B.4 Lateral extent of trichloroethene in groundwater at the Y-12 National Security Complex, East

B.5 Lateral extent of cis-1,2-dichloroethene in groundwater at the Y-12 National Security Complex, West...

B.6 Lateral extent of cis-1,2-dichloroethene in groundwater at the Y-12 National Security Complex, East

B.7 Lateral extent of 1,1-dichloroethene in groundwater at the Y-12 National Security Complex, West

B.8 Lateral extent of 1,1-dichloroethene in groundwater at the Y-12 National Security Complex, East. 


\section{CONTENTS (continued)}

APPENDIX B: CONTAMINANT PLUME MAPS (continued)

B.9 Lateral extent of vinyl chloride in groundwater at the Y-12 National Security Complex, West

B.10 Lateral extent of vinyl chloride in groundwater at the Y-12 National Security Complex, East.

B.11 Lateral extent of carbon tetrachloride in groundwater at the Y-12 National Security Complex, West

B.12 Lateral extent of carbon tetrachloride in groundwater at the Y-12 National Security Complex, East...

B.13 Lateral extent of nitrate in groundwater at the Y-12 National Security Complex, West.

B.14 Lateral extent of nitrate in groundwater at the Y-12 National Security Complex, East.

B.15 Lateral extent of uranium (total) in groundwater at the Y-12 National Security Complex, West ......

B.16 Lateral extent of uranium (total) in groundwater at the Y-12 National Security Complex, East.

B.17 Lateral extent of technetium-99 in groundwater at the Y-12 National Security Complex, West

B.18 Lateral extent of technetium-99 in groundwater at the Y-12 National Security Complex, East.

B.19 Lateral extent of gross alpha activity in groundwater at the Y-12 National Security Complex, West

B.20 Lateral extent of gross alpha activity in groundwater at the Y-12 National Security Complex, East.

B.21 Lateral extent of gross beta activity in groundwater at the Y-12 National Security Complex, West

B.22 Lateral extent of gross beta activity in groundwater at the Y-12 National Security Complex, East. 


\subsection{INTRODUCTION}

This report presents data summary tables (Appendix A) and maps (Appendix B) used to define and illustrate the approximate lateral extent of groundwater contamination at the U.S. Department of Energy (DOE) Y-12 National Security Complex (Y-12) in Oak Ridge, Tennessee. The data tables and maps address the following primary (i.e., most widespread and mobile) organic, inorganic, and radiological contaminants in the groundwater:

\section{Organic Contaminants}

- Tetrachloroethene (PCE)

- Trichloroethene (TCE)

- cis-1,2-Dichloroethene (c12DCE)

- 1,1-Dichloroethene (11DCE)

- Vinyl chloride (VC)

- Carbon tetrachloride (CTET)

\section{Inorganic Contaminants}

- Nitrate

- Uranium (total)

\section{$\underline{\text { Radiological Contaminants }}$}

- Gross alpha activity

- Gross beta activity

- Technetium-99 (Tc-99)

Maps delineating the approximate extent of these primary groundwater contaminants were prepared to support Groundwater Protection Program (GWPP) surveillance monitoring of contaminated groundwater at Y-12 per the requirements of applicable DOE Orders, as described in the Y-12 Groundwater Protection Program Management Plan (B\&W Y-12 2006). For the purposes of the GWPP, these maps update analogous groundwater contaminant plume maps presented in the Report on the Remedial Investigation of Bear Creek Valley at the Oak Ridge Y-12 Plant, Oak Ridge, Tennessee (DOE 1997) and the Report on the Remedial Investigation of the Upper East Fork Poplar Creek Characterization Area at the Oak Ridge Y-12 Plant, Oak Ridge, Tennessee (DOE 1998). Groundwater contaminant plume maps in both remedial investigation (RI) reports delineate the approximate extent of nitrate, uranium, volatile organic compounds (VOCs), gross alpha activity, and gross beta activity based on groundwater sampling/analysis results obtained more than 15 years ago. Groundwater contaminant plume maps in Appendix B are based on the extensive subsequent and more recent sampling/analysis results, including data for additional sampling locations not used for the respective RIs, which characterize respective plume boundaries more accurately in some areas and/or reflect substantially different (higher or lower) contaminant concentrations. In the time period since the RI maps were produced, the GWPP collected groundwater samples from previously unsampled wells and encountered at wells 55-3A, 55-3B, and 55-3C the highest VOC concentrations at Y-12. Also, a pumping plume capture well at the east end of the complex (GW-845) has effectively reduced organic contaminant concentrations in wells located near the Oak Ridge Reservation boundary (e.g., Westbay ${ }^{\mathrm{TM}}$ well GW-722). Other variations in the current plume maps reflect changes in concentrations over time (long-term contaminant concentration trends).

Under the limitations and considerations outlined below, the groundwater contaminant plume maps in this report are sufficient for delineating the generalized extent of groundwater contamination at Y-12, particularly the areas where contaminant concentrations are highest and most likely to pose the greatest risk to human health and the environment:

- The groundwater contaminant plume maps are simplified and idealized two-dimensional illustrations of the complex, heterogeneous, and three-dimensional distribution of contaminants in the groundwater at $\mathrm{Y}-12$.

- The delineated contaminant plume boundaries and color-coded concentration shading shown on each map were approximated, inferred, and extrapolated based on the network of groundwater sampling locations, available historical data (including the above-referenced RI reports), 
interpretive assumptions related to the hydrogeologic characteristics (e.g., preferential contaminant transport in directions that parallel geologic strike of the bedrock), and subjective professional judgment.

- Contaminant plume boundaries delineated in most areas at Y-12 define the approximate extent of contamination in shallow groundwater less than $100 \mathrm{ft}$ below ground surface (bgs) and reflect the maximum downgradient transport from the applicable source area(s). In several areas at Y-12, however, contaminant concentrations remain highest in groundwater from more than $100 \mathrm{ft} b g s$. The generalized contaminant plume maps reflect data from all depth ranges within the groundwater monitoring network. Consequently, the color-coded concentration shading on the contaminant plume maps may encompass shallower groundwater sampling locations shown with concentrations values that are below the specified color-coded range. 


\subsection{GROUNDWATER CONTAMINANT PLUME DELINEATION}

The following discussion describes the sampling locations, calculated contaminant concentrations, plume boundary values, and paired map format used to define, quantify, delineate, and illustrate the approximate extent of the primary organic, inorganic, and radiological contaminants in groundwater at Y-12.

\subsection{SAMPLING LOCATIONS}

Groundwater sampling/analysis results for a total of 222 wells, three springs, two building basement sumps, and an underdrain sump at Lake Reality were used to define the approximate extent of groundwater contamination at Y-12. All of the wells and springs currently retain "active" status per the $Y-12$ Groundwater Protection Program Monitoring Optimization Plan for Groundwater Monitoring Wells at the U.S. Department of Energy Y-12 National Security Complex, Oak Ridge, Tennessee. (B\&W Y-12 2009), which describes the criteria used to optimize implementation of the GWPP in terms of surveillance monitoring sampling locations, sampling frequency and priority, and laboratory analyses. For each well, the data summarized in Appendix A include the respective depths to the top and bottom of the monitored interval. Approximately two-thirds (148 wells) of the wells yield groundwater from less than $100 \mathrm{ft}$ bgs, with most of those (101 wells) being less than $50 \mathrm{ft} \mathrm{bgs.} \mathrm{About} \mathrm{one-third} \mathrm{(74} \mathrm{wells)} \mathrm{of} \mathrm{the} \mathrm{wells} \mathrm{have}$ monitored intervals more than $100 \mathrm{ft}$ bgs, including 21 wells more than $200 \mathrm{ft}$ bgs, five of which are equipped with Westbay multiport sampling systems configured to collect samples from several depth intervals in each well.

All of the sumps and springs and approximately $85 \%$ of the wells are located in Bear Creek Valley (BCV), where groundwater contamination from multiple source areas is widespread, and the remaining wells are located on Chestnut Ridge, where groundwater contamination of relatively limited extent occurs at only a few source areas. In BCV, the well locations are distributed between the Bear Creek watershed (85 wells) west of Y-12 and the adjacent Upper East Fork Poplar Creek watershed (102 wells) extending east to Scarboro Road. Most of the wells on Chestnut Ridge are located along the crest of the ridge directly south of $\mathrm{Y}-12$.

\subsection{CONTAMINANT CONCENTRATIONS}

Groundwater sampling/analysis data downloaded from the Groundwater Information System (GIMS) maintained by the GWPP and from the Oak Ridge Environmental Information System (OREIS) were used to quantify contaminant concentrations. Groundwater sampling/analysis results obtained by the GWPP and other organizations are compiled in the GIMS, with the combined data managed in accordance with the Y-12 Groundwater Protection Program Data Management Plan (B\&W Y-12 2012). However, the data downloaded from GIMS did not include available analytical results for duplicate groundwater samples, filtered groundwater samples, or the groundwater samples obtained by the GWPP (during 2008) to evaluate the suitability of passive groundwater sampling methods/equipment (Hydrasleeve and passive diffusion bag samplers) for Y-12 surveillance monitoring purposes.

Average contaminant concentrations calculated from analytical results reported for groundwater samples collected between January 1, 2008 and December 31, 2012 were used to delineate the approximate lateral extent of groundwater contamination and associated color-coded ranges of contaminant concentrations shown on each contaminant plume map in Appendix B. For each groundwater sampling location, the data summary tables in Appendix A show the calculated average concentrations of the organic contaminants 
(Table A.1) and the inorganic and radiological contaminants (Table A.2) along with other pertinent information, including the number of sampling/analysis results and associated range of sampling dates.

Average concentrations used for contaminant plume delineation purposes are based on total concentrations detected in unfiltered groundwater samples from each well, spring, and sump, including estimated concentrations of organic contaminants below the analytical reporting limits. For calculation purposes, a concentration of zero was assumed for all non-detect analytical results reported for organic and inorganic contaminants, and results for radiological contaminants that are below the associated minimum detectable activity (MDA) and/or total propagated uncertainty.

Calculated average contaminant concentrations do not include groundwater sampling/analysis results (if any) reported as "Not Sampled" or "Not Analyzed" for each applicable sampling location. Groundwater sampling/analysis results that do not meet applicable data quality objectives (e.g., false positive results for VOCs) described in the above-referenced GWPP data management plan also were excluded from the calculated average concentrations, as were a total of 20 groundwater sampling/analysis results (listed in the Appendix A data summary table explanations) identified as suspected outliers compared to available historical data for the applicable sampling locations.

As noted previously, five of the wells used to delineate the approximate extent of groundwater contamination are equipped with multi-port sampling systems that yield groundwater samples from several different depth intervals. For each of these wells, the depth interval with the highest calculated average concentration of the applicable organic, inorganic, or radiological contaminants (see data tables in Appendix A) was used for contaminant plume delineation purposes.

Instead of showing average concentration values of zero, each of the groundwater contaminant plume maps in Appendix B use open (unfilled) symbols/markers to designate the applicable groundwater sampling locations having 100\% non-detect analytical results for the contaminant. Respective contaminant plume maps for gross alpha activity, gross beta activity, and Tc-99 also use the same open symbols/markers for applicable sampling locations with average concentration values below $5 \mathrm{pCi} / \mathrm{L}, 10 \mathrm{pCi} / \mathrm{L}$, and $15 \mathrm{pCi} / \mathrm{L}$, respectively, which the GWPP designates as programmatic MDAs for the purposes of surveillance monitoring at $\mathrm{Y}-12$.

\subsection{PLUME BOUNDARY VALUES}

Groundwater contaminant plume maps in Appendix B use the boundary values and color-coded shading listed below to delineate and illustrate the approximate extent and concentrations of the primary organic contaminants (in micrograms per liter $[\mu \mathrm{g} / \mathrm{L}]$ ), inorganic contaminants (in milligrams per liter $[\mathrm{mg} / \mathrm{L}]$ ), and radiological contaminants (in picoCuries per liter $[\mathrm{pCi} / \mathrm{L}]$ ) in the groundwater at $\mathrm{Y}-12$. The selected plume boundary values are current federal and state drinking water maximum contaminant levels (MCLs) established for PCE, TCE, c12DCE, 11DCE, VC, CTET, nitrate, uranium, and gross alpha activity. Plume boundary values for gross beta activity and Tc-99 represent threshold levels that correspond to a 4 millirem per year dose equivalent (the drinking water MCL for gross beta activity). For comparative context, the plume boundaries and color-coded concentration shading shown on the respective plume maps for PCE, TCE, c12DCE, 11DCE, VC, and CTET are superimposed over grey shading that delineates summed concentrations (above $5 \mu \mathrm{g} / \mathrm{L}$ ) for all detected VOCs. 


\begin{tabular}{rccccc}
\hline \multirow{2}{*}{ Contaminant } & \multirow{2}{*}{$\begin{array}{c}\text { Concentration } \\
\text { Units }\end{array}$} & $\begin{array}{c}\text { Boundary } \\
\text { Value }\end{array}$ & \multicolumn{3}{c}{ Concentration Range } \\
\cline { 4 - 6 } & & 5 & $5-99$ & $100-999$ & $\geq 1,000$ \\
$\mathrm{PCE}$ & $\mu \mathrm{g} / \mathrm{L}$ & 5 & $5-99$ & $100-999$ & $\geq 1,000$ \\
$\mathrm{TCE}$ & $\mu \mathrm{g} / \mathrm{L}$ & 70 & $70-699$ & $700-6999$ & $\geq 7,000$ \\
$\mathrm{c} 12 \mathrm{DCE}$ & $\mu \mathrm{g} / \mathrm{L}$ & 7 & $7-99$ & $100-999$ & $\geq 1,000$ \\
$11 \mathrm{DCE}$ & $\mu \mathrm{g} / \mathrm{L}$ & 2 & $2-99$ & $100-999$ & $\geq 1,000$ \\
$\mathrm{VC}$ & $\mu \mathrm{g} / \mathrm{L}$ & 5 & $5-99$ & $100-999$ & $\geq 1,000$ \\
$\mathrm{CTET}$ & $\mu \mathrm{g} / \mathrm{L}$ & 10 & $10-99$ & $100-999$ & $\geq 1000$ \\
Nitrate & $\mathrm{mg} / \mathrm{L}$ & 0.03 & $0.03-0.099$ & $0.1-0.99$ & $\geq 1.0$ \\
Uranium (total) & $\mathrm{mg} / \mathrm{L}$ & 15 & $15-99$ & $100-999$ & $\geq 1,000$ \\
Gross alpha activity & $\mathrm{pCi} / \mathrm{L}$ & 50 & $50-499$ & $500-4,999$ & $\geq 5,000$ \\
Gross beta activity & $\mathrm{pCi} / \mathrm{L}$ & 900 & $900-8,999$ & $9,000-89,999$ & $\geq 90,000$ \\
Tc-99 & $\mathrm{pCi} / \mathrm{L}$ & & & &
\end{tabular}

\subsection{PAIRED MAP FORMAT}

Appendix B provides two maps of equal size $(11 \mathrm{x} 17 \mathrm{in}$.$) and scale (1 \mathrm{in} .=900 \mathrm{ft})$ that illustrate the extent of each primary organic, inorganic, and radiological groundwater contaminant: a "West"-designated map that delineates the contaminant plume boundaries and color-coded concentrations in the Bear Creek watershed downgradient to the west of the hydrologic divide located at the west end of Y-12, and an "East" - designated map that delineates the contaminant plume boundaries and color-coded concentrations in the Upper East Fork Poplar Creek watershed downgradient to the east of the hydrologic divide, including areas along the crest of Chestnut Ridge directly south of Y-12 and a section of Union Valley east of Scarboro Road. Additionally, the paired maps for each primary groundwater contaminant are presented in a configuration such that, when unfolded, the maps together provide a complete west-to-east (left-to-right) profile of the lateral extent and concentrations of the contaminant.

The Y-12 GWPP monitoring network includes areas not shown on the paired maps because none of the locations yield groundwater with elevated contaminant concentrations (i.e., greater than boundary values shown above). The map extents are designed to show all areas with elevated contaminant concentrations and provide as much detail as possible. For example, some wells located in Union Valley east of the "East"-designated map boundary have low levels of VOCs within the gray-shading for summed VOCs $>5 \mu \mathrm{g} / \mathrm{L}$, but do not have individual compound concentrations that exceed applicable drinking water MCLs. 


\subsection{REFERENCES}

B\&W Y-12. 2006. Y-12 Groundwater Protection Program Management Plan.

B\&W Y-12. 2009. Y-12 Groundwater Protection Program Monitoring Optimization Plan for Groundwater Monitoring Wells at the U.S. Department of Energy Y-12 National Security Complex, Oak Ridge, Tennessee. Prepared by Elvado Environmental LLC (Y/TS-2031/R1).

B\&W Y-12. 2012. Y-12 Groundwater Protection Program Data Management Plan. Prepared by the Environment, Safety, and Health Division and the Information Technology Organization (Y/TS-2007/R1).

DOE. 1997. Report on the Remedial Investigation of Bear Creek Valley at the Oak Ridge Y-12 Plant, Oak Ridge, Tennessee, U.S. Department of Energy, Office of Environmental Management, Oak Ridge, TN (DOE/OR/01-1455/V1\&D2).

DOE. 1998. Report on the Remedial Investigation of the Upper East Fork Poplar Creek Characterization Area at the Oak Ridge Y-12 Plant, Oak Ridge, Tennessee, U.S. Department of Energy, Office of Environmental Management, Oak Ridge, TN (DOE/OR/01-1641/D1\&V1). 



\section{APPENDIX A}

\section{DATA SUMMARY TABLES}





\section{EXPLANATION}

\section{Sampling Point:}

GW - Groundwater monitoring well (also 1090 and hyphenated numbers [e.g., 55-3A])

LRS - Lake Reality Sump

SCR - South Chestnut Ridge (tributary prefix for spring sampling locations)

SS - South Side (of Bear Creek, spring sampling station)

(EEVOC) - East End VOC plume extraction well, sampling location is at the influent to the Removal Action Treatment Facility

(WB) - Westbay ${ }^{\mathrm{TM}}$ well compiled data. The row with this designation shows the maximum concentration for all depths in the wells (shown in bold typeface). Information for each sampling port is presented beneath the compilation row.

\section{Location:}

B4 - Beta-4 Security Pits

B8110 - Building 81-10

B9103 - Building 9103

B9201-2 - Building 9201-2

B9201-5 - Building 9201-5

BG - Bear Creek Burial Grounds WMA

CDLVII - Construction/Demolition Landfill VII

CPT - Coal Pile Trench

CRBAWP - Chestnut Ridge Borrow Area Waste Pile

CRSDB - Chestnut Ridge Sediment Disposal Basin

CRSP - Chestnut Ridge Security Pits

ECRWP - East Chestnut Ridge Waste Pile

EMWMF - Environmental Management Waste Management Facility

EXP - Exit Pathway Monitoring Location: Maynardville Limestone Picket (-A, -B, -C, -E, -I, -J, and -W)

Along Scarboro Road in the gap through Pine Ridge (-SR)

East of Scarboro Road in Union Valley (-UV)

Spring sampling location (SW)

FCAP - Filled Coal Ash Pond

FF - Fuel Facility; former Garage Underground Tanks near Bldgs 9754, 9754-2, and 9754-3

FTF - Fire Training Facility

GRID - Comprehensive Groundwater Monitoring Plan Grid Location (MMES 1990b)

KHQ - Kerr Hollow Quarry

LD - Lysimeter Demonstration

LII - Industrial Landfill II

LIV - Industrial Landfill IV

LV - Industrial Landfill V

NHP - New Hope Pond

OLF - Oil Landfarm WMA

RG - Rust Garage Area

RS - Rust Spoil Area 


\section{EXPLANATION}

Location: (continued)

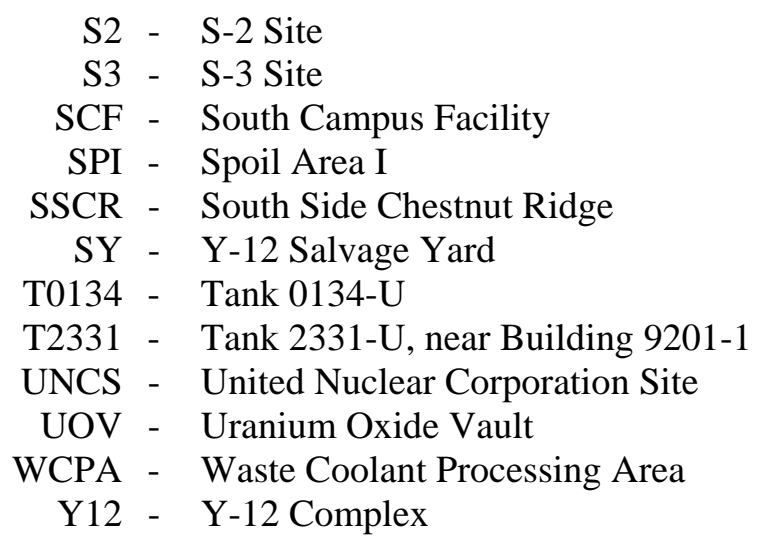

\section{Monitored Interval:}

Top - Depth to top of filter pack or open-hole (feet below ground surface)

Bottom - Depth to bottom of filter pack or open-hole (feet below ground surface)

. - Unknown or not applicable (Westbay ${ }^{\mathrm{TM}}$ ports)

\section{Date Range:}

Shows the first and last (most recent) sampling date in the data set used to calculate the average concentration/activity value.

$$
\text { NS - Not sampled }
$$

\section{Number of Samples:}

Indicates the number of samples used to calculate the average concentration/activity value.

$$
\text { NS -Not sampled }
$$

The number of samples is the same for all organic contaminants on Table A.1, but may differ for inorganic and radiological contaminants as shown in three columns on Table A.2.

N/U - Nitrate and uranium

A/B - Gross alpha and gross beta activities

Tc-99 - Technetium-99 activity 


\section{EXPLANATION}

\section{Average Calendar Year 2008 to 2012 (CY 08-12) Concentration:}

Except for uranium, the average concentration is rounded to the nearest whole number.

NA - Not analyzed

0 - Not detected

Table A.1 provides the average concentration in micrograms per liter $(\mu \mathrm{g} / \mathrm{L})$ for the following primary organic contaminants:

$$
\begin{aligned}
& \text { PCE - } \text { Tetrachloroethene } \\
& \text { TCE - Trichloroethene } \\
& \text { c12DCE - cis-1,2-Dichloroethene } \\
& \text { 11DCE - 1,1-Dichloroethene } \\
& \text { VC - Vinyl chloride } \\
& \text { CTET - Carbon Tetrachloride }
\end{aligned}
$$

Table A.2 provides the average concentration in milligrams per liter $(\mathrm{mg} / \mathrm{L})$ for the nitrate and uranium and in picoCuries per liter (pCi/L) for gross alpha activity, gross beta activity, and

\begin{tabular}{|c|c|c|c|c|c|c|}
\hline Well & Date & Contaminant & Units & Result & $\begin{array}{c}\text { Lab } \\
\text { Qual. }\end{array}$ & $\begin{array}{c}\text { Evaluation } \\
\text { Qualifier }\end{array}$ \\
\hline \multicolumn{7}{|l|}{ Table A.1 } \\
\hline \multirow[t]{4}{*}{ GW-068 } & 08/21/12 & 1,1-Dichloroethene & $\mathrm{ug} / \mathrm{L}$ & 34 & & Q \\
\hline & & Trichloroethene & & 12 & & $\mathrm{Q}$ \\
\hline & & Vinyl chloride & & 28 & & $\mathrm{Q}$ \\
\hline & & cis-1,2-Dichloroethene & & 290 & $\mathrm{D}$ & $\mathrm{Q}$ \\
\hline \multirow[t]{3}{*}{ GW-383 } & $08 / 30 / 11$ & Tetrachloroethene & ug/L & 37 & & $\mathrm{Q}$ \\
\hline & & Trichloroethene & & 14 & & Q \\
\hline & & cis-1,2-Dichloroethene & & 840 & $\mathrm{D}$ & $\mathrm{Q}$ \\
\hline GW-557 & $07 / 23 / 12$ & Tetrachloroethene & $\mathrm{ug} / \mathrm{L}$ & 31.8 & & $\mathrm{Q}$ \\
\hline GW-648 & $02 / 13 / 08$ & Trichloroethene & $\mathrm{ug} / \mathrm{L}$ & 10 & & Q \\
\hline \multirow[t]{2}{*}{ GW-686 } & $05 / 13 / 09$ & Tetrachloroethene & $\mathrm{ug} / \mathrm{L}$ & 6 & & $\mathrm{Q}$ \\
\hline & & Trichloroethene & & 4 & $\mathrm{~J}$ & $\mathrm{Q}$ \\
\hline \multicolumn{7}{|l|}{ Table A.2 } \\
\hline GW-225 & $02 / 26 / 09$ & Nitrate Nitrogen & $\mathrm{mg} / \mathrm{L}$ & 0.313 & & $Q$ \\
\hline GW-246 & $03 / 12 / 08$ & Technetium-99 & $\mathrm{pCi} / \mathrm{L}$ & 140,000 & & Q \\
\hline GW-274 & $04 / 21 / 09$ & Gross Beta & $\mathrm{pCi} / \mathrm{L}$ & 3.4 & & Q \\
\hline GW-505 & $04 / 20 / 09$ & Uranium & $\mathrm{mg} / \mathrm{L}$ & 0.0629 & & $\mathrm{Q}$ \\
\hline GW-562 & $07 / 19 / 12$ & Gross Beta & $\mathrm{pCi} / \mathrm{L}$ & 27.5 & & Q \\
\hline GW-615 & $09 / 15 / 10$ & Uranium & $\mathrm{mg} / \mathrm{L}$ & 0.0958 & & $\mathrm{Q}$ \\
\hline GW-633 & $04 / 28 / 09$ & Gross Beta & $\mathrm{pCi} / \mathrm{L}$ & 1.7 & & $\mathrm{Q}$ \\
\hline GW-725 & $02 / 25 / 09$ & Nitrate Nitrogen & $\mathrm{mg} / \mathrm{L}$ & 0.315 & & $\mathrm{Q}$ \\
\hline GW-726-06 & $05 / 04 / 09$ & Gross Alpha & $\mathrm{pCi} / \mathrm{L}$ & 41 & & $\mathrm{Q}$ \\
\hline
\end{tabular}
technetium-99 (Tc-99) activity.

All results with a data evaluation qualifier of “Q” per the Y-12 GWPP data evaluation/validation procedure (suspected outliers) were reviewed in conjunction with subsequent monitoring data. The table below lists results excluded from the average calculations.

Suspected outlier results excluded from average calculations

Results shown in bold typeface are higher than historical measurements. 



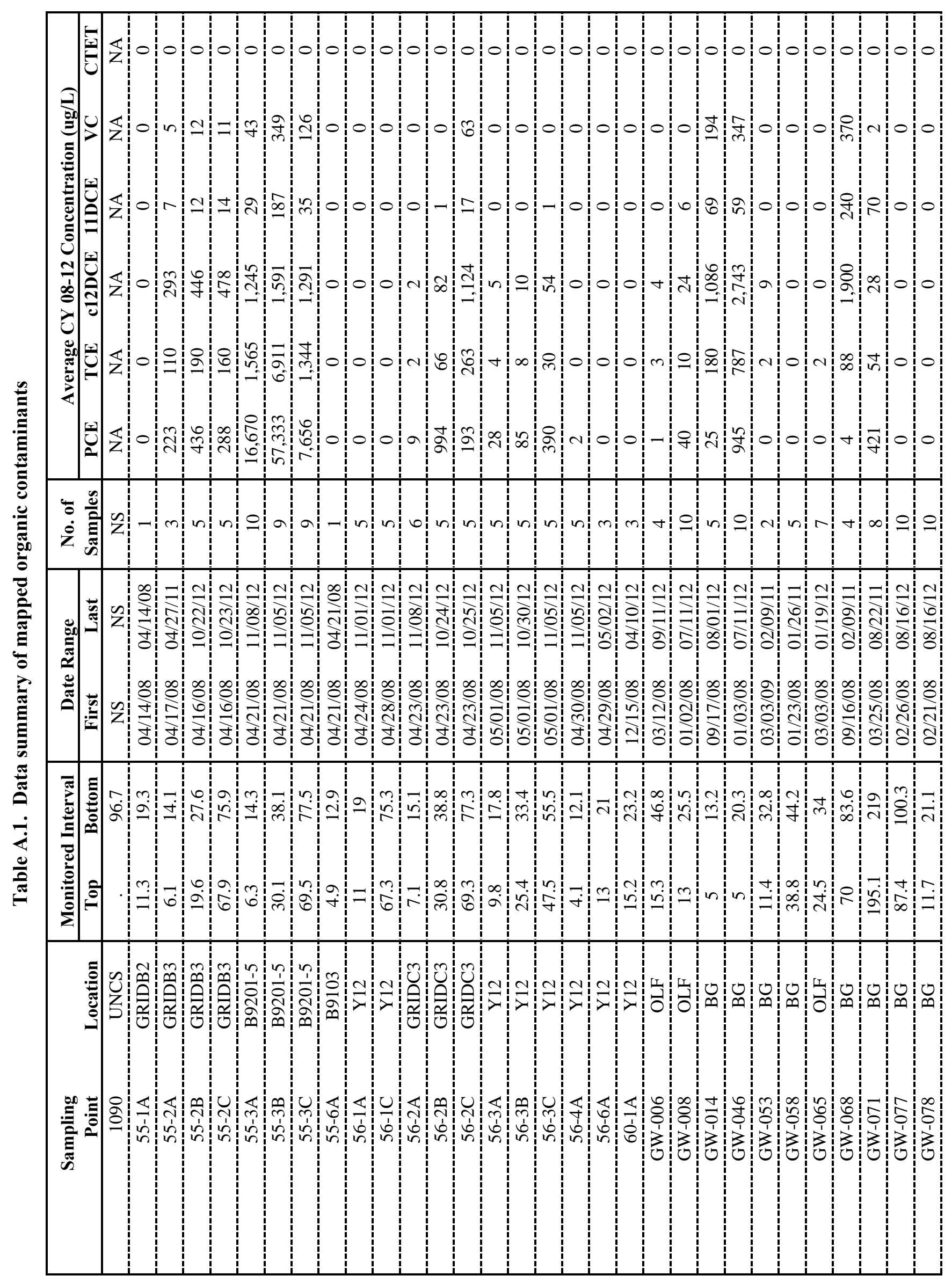




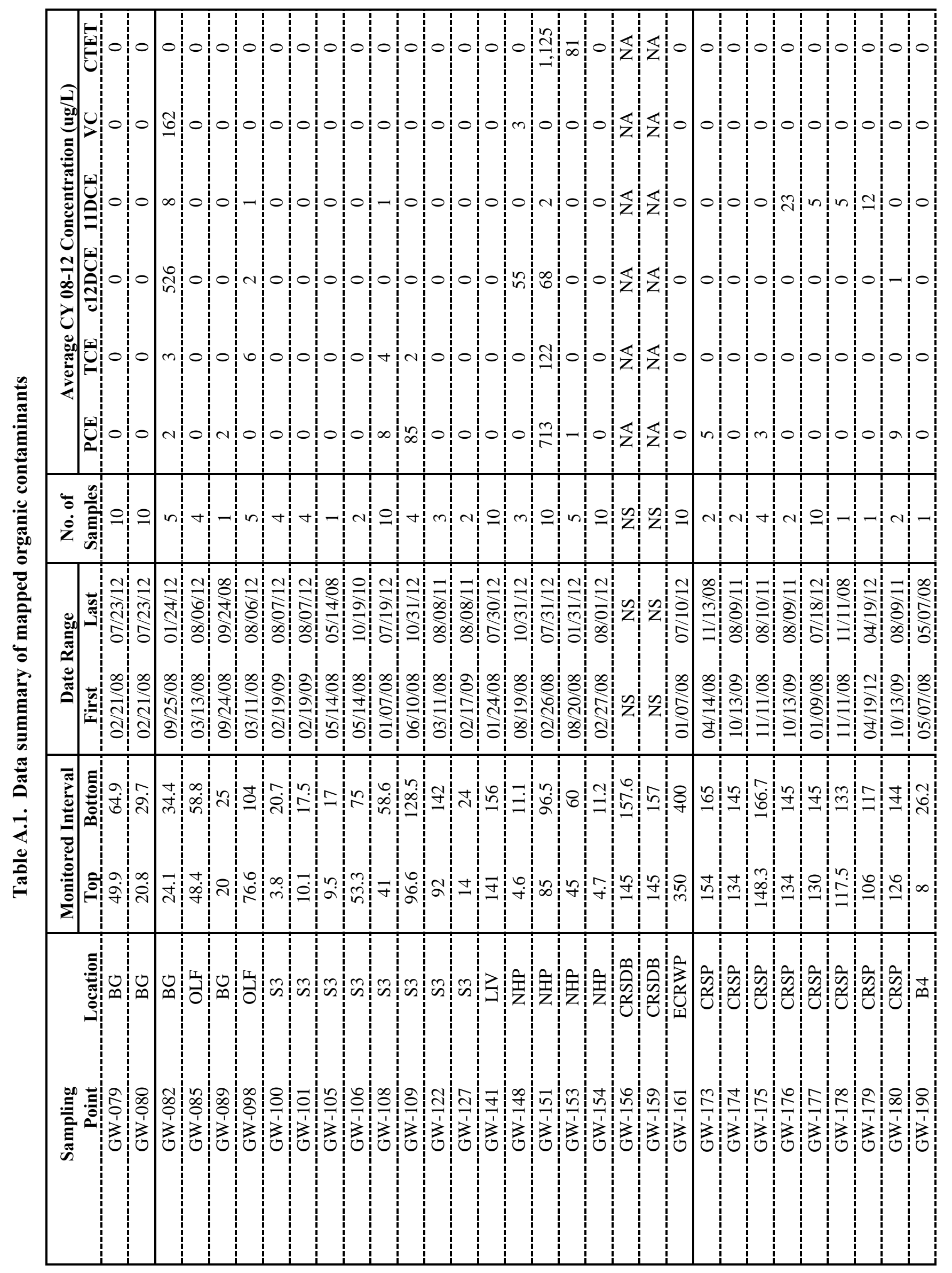




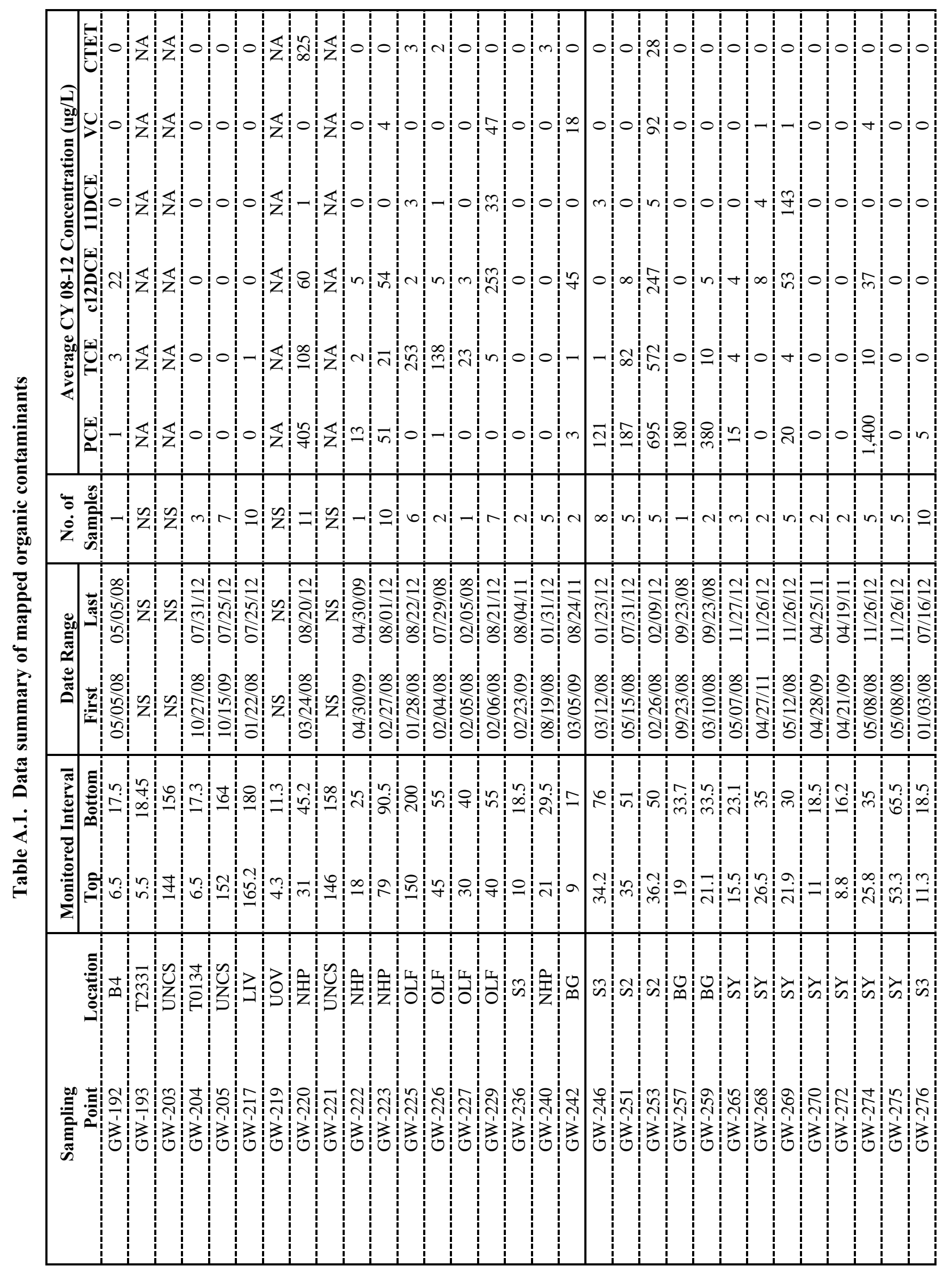




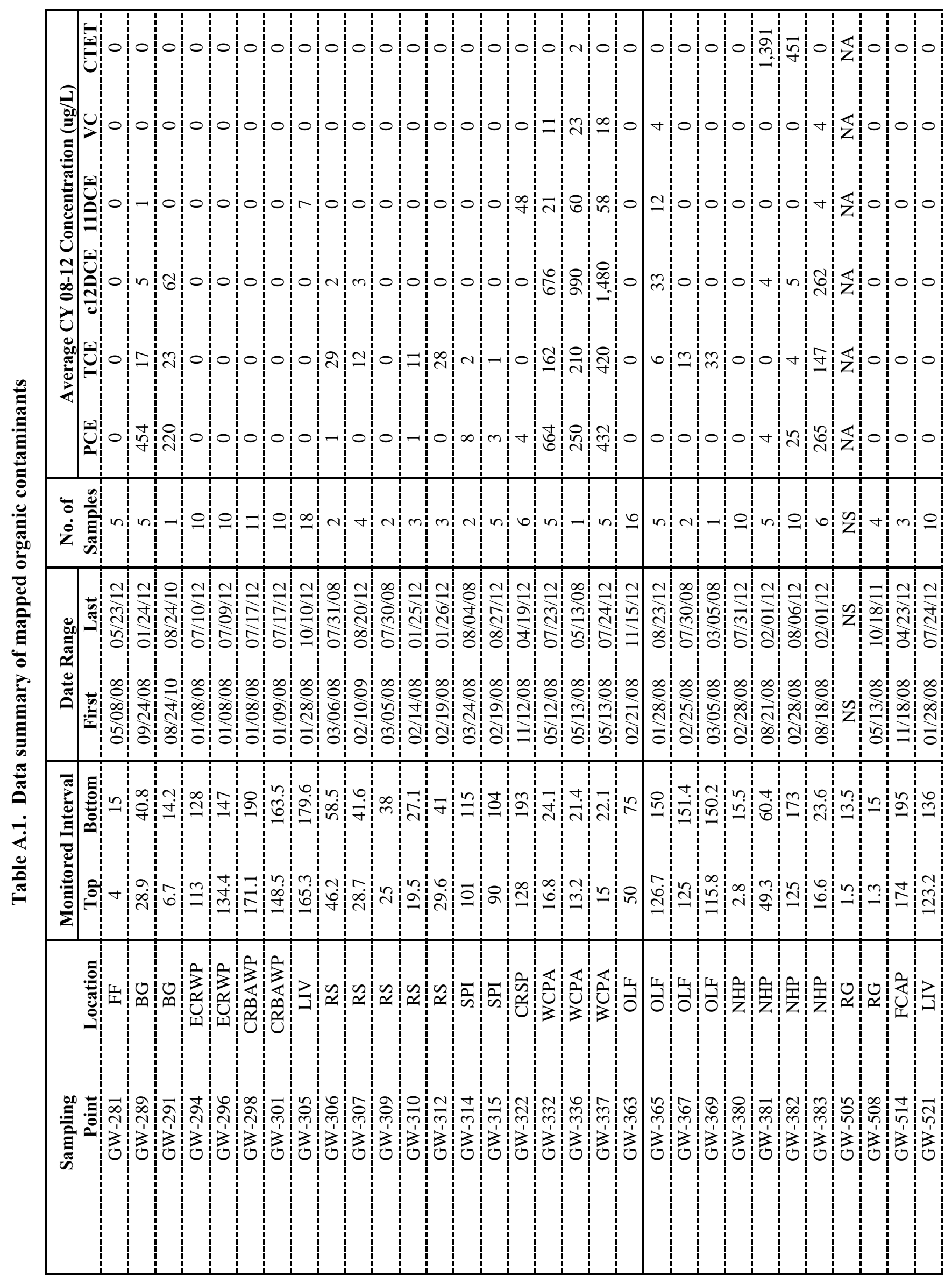




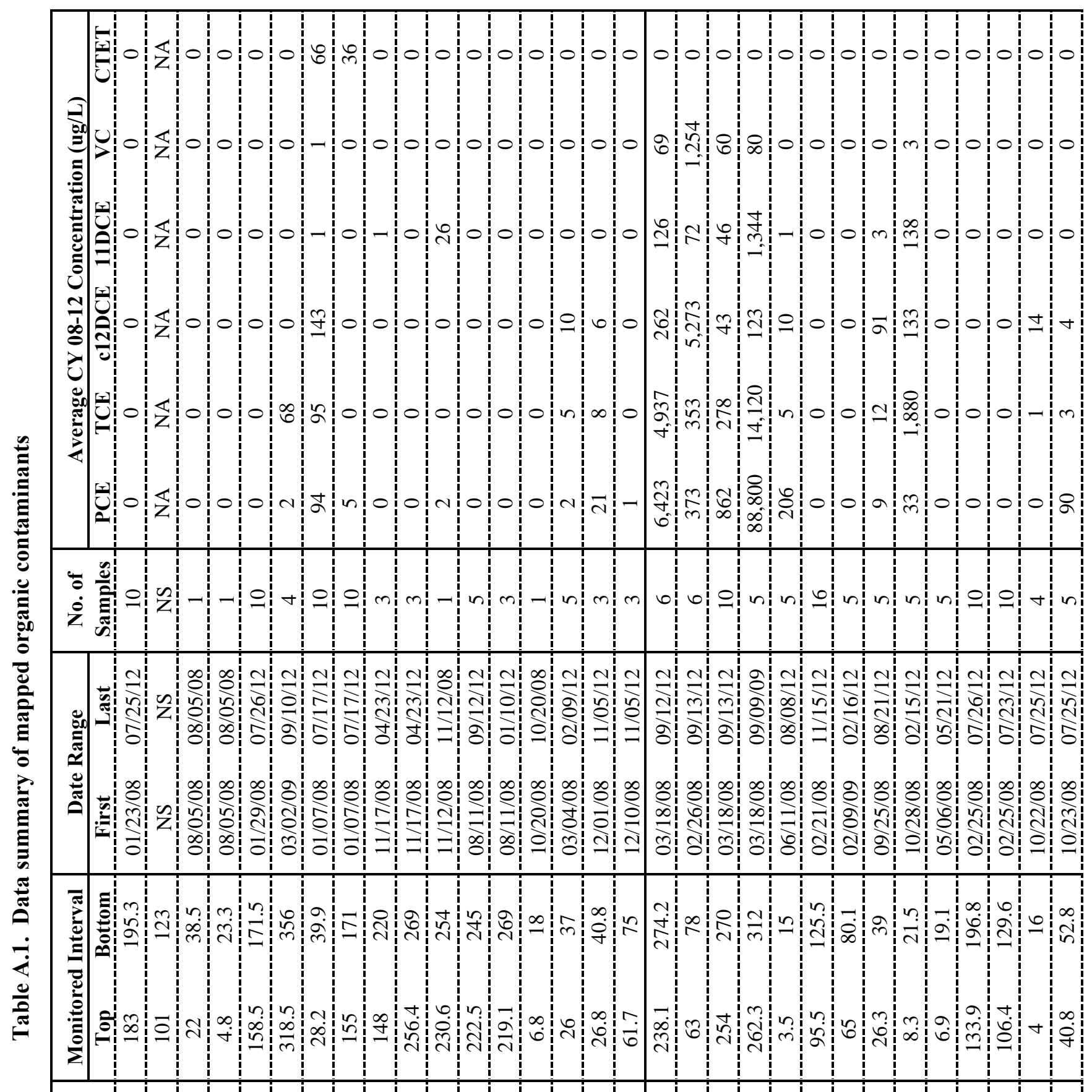

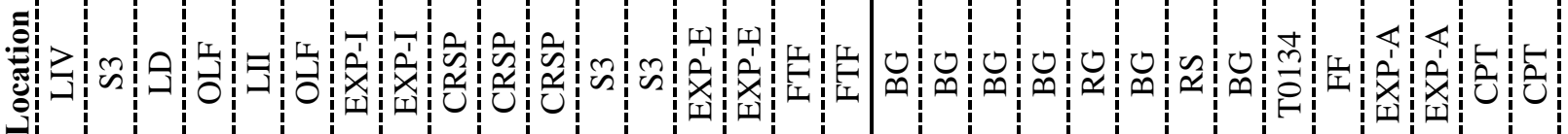

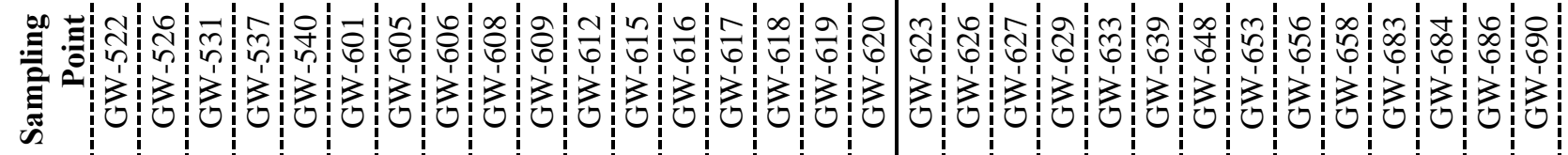




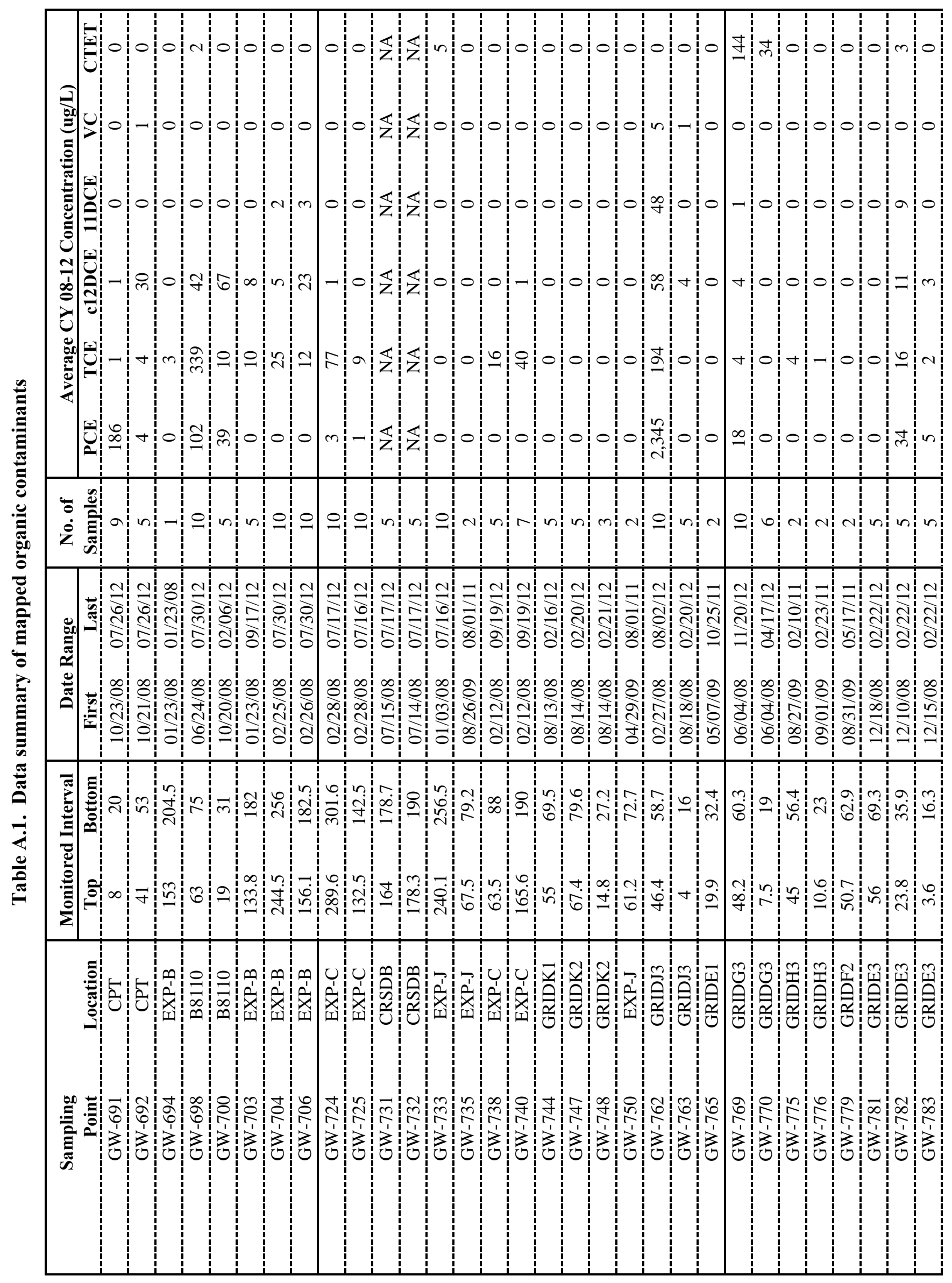




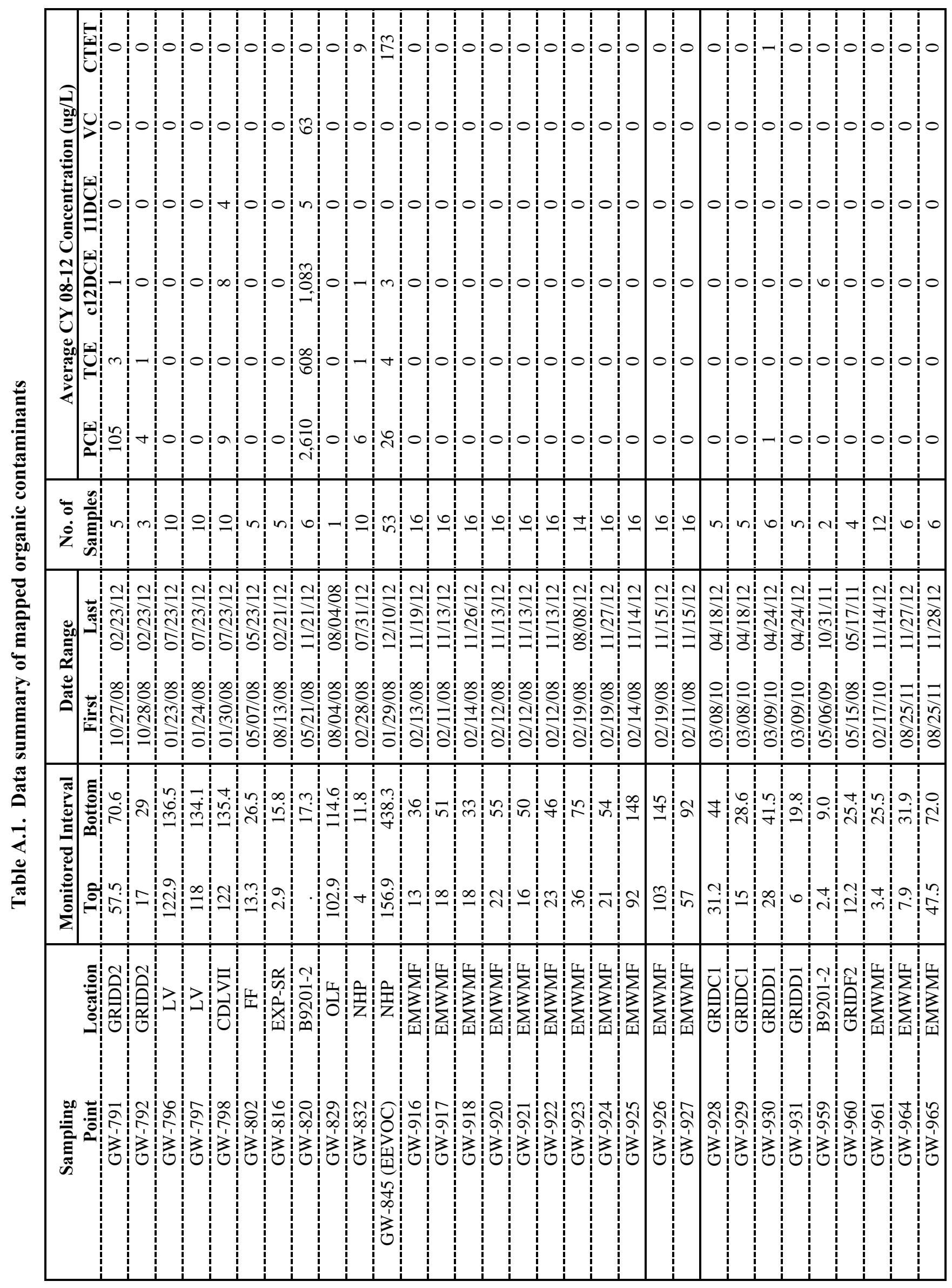




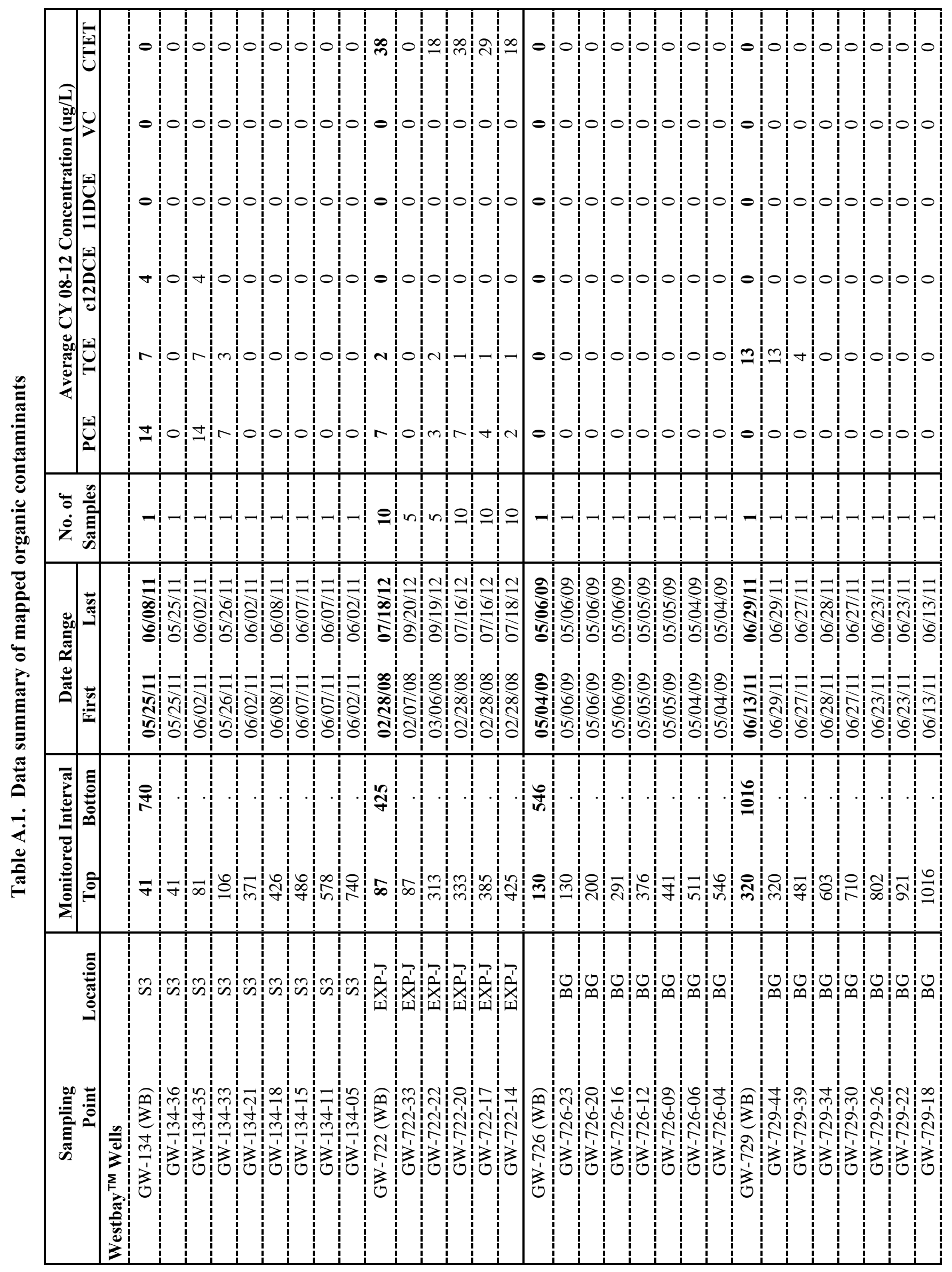




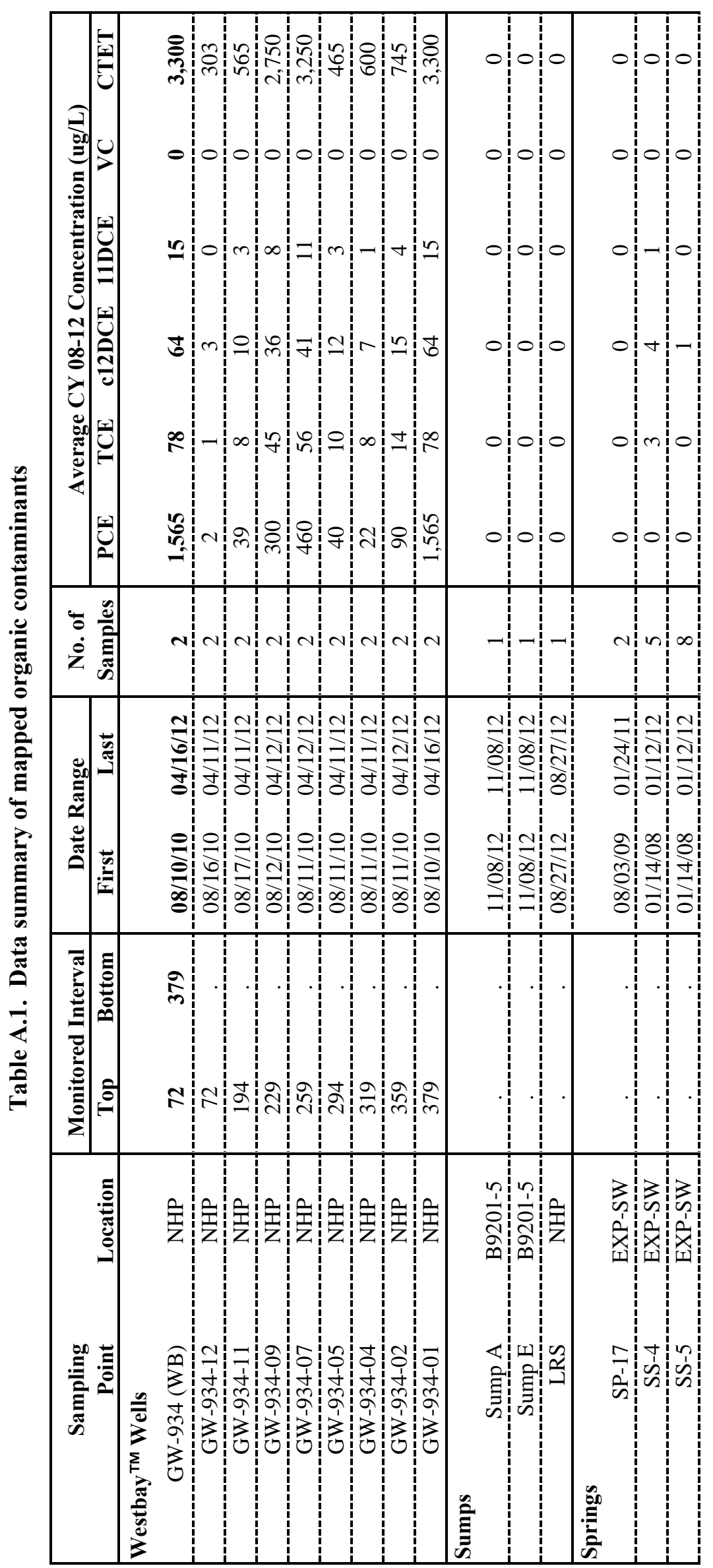


A-10 


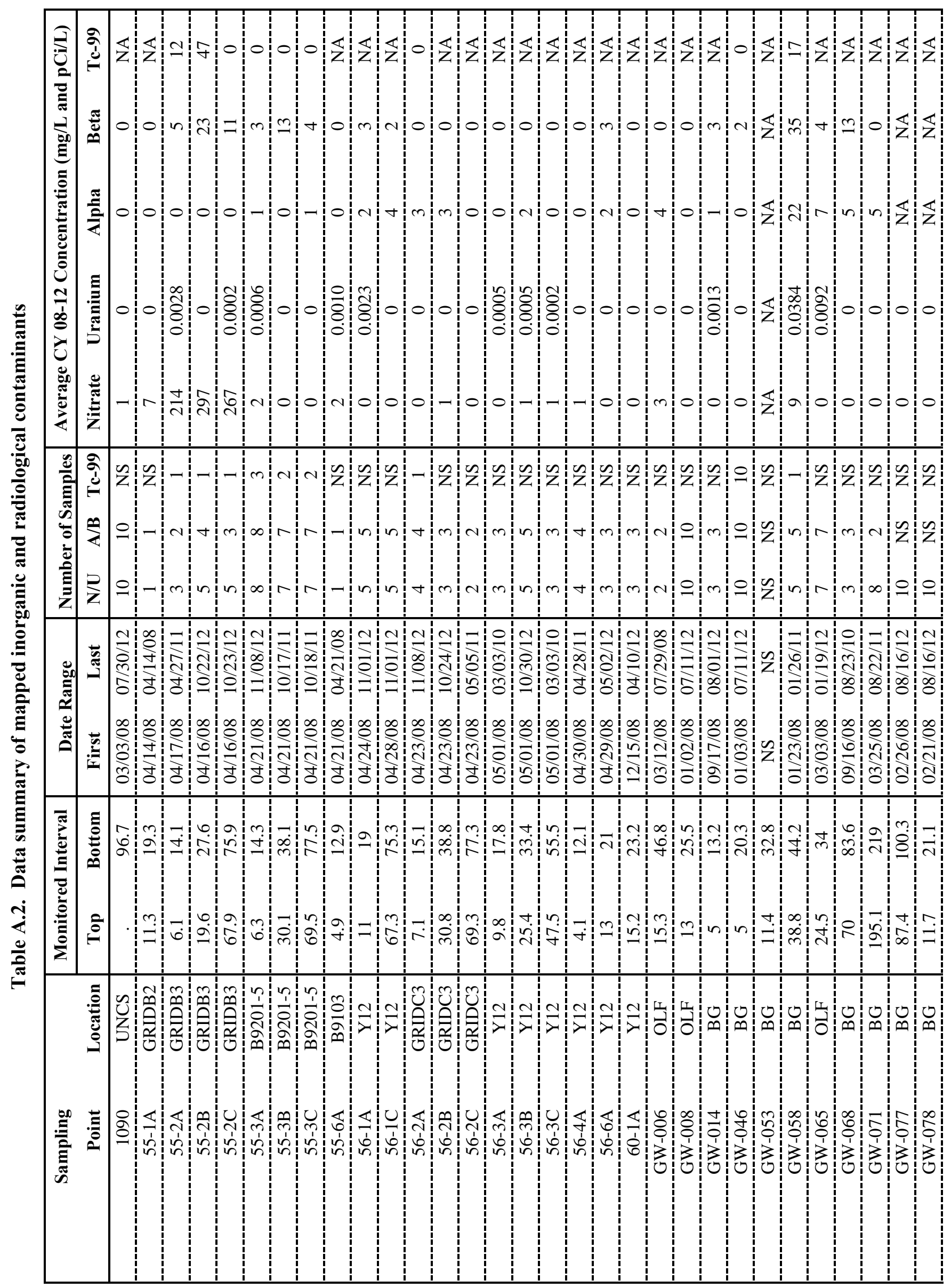




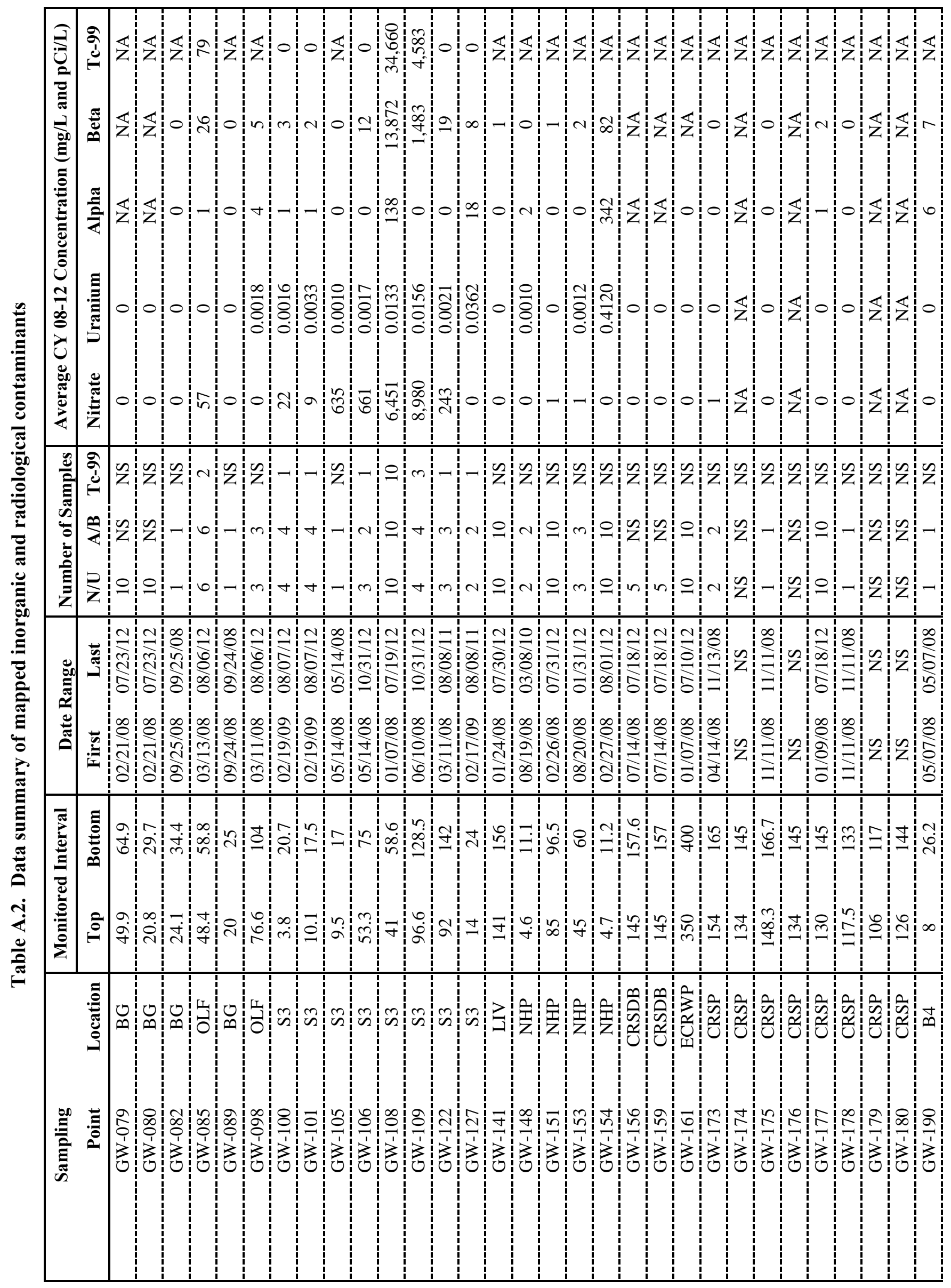




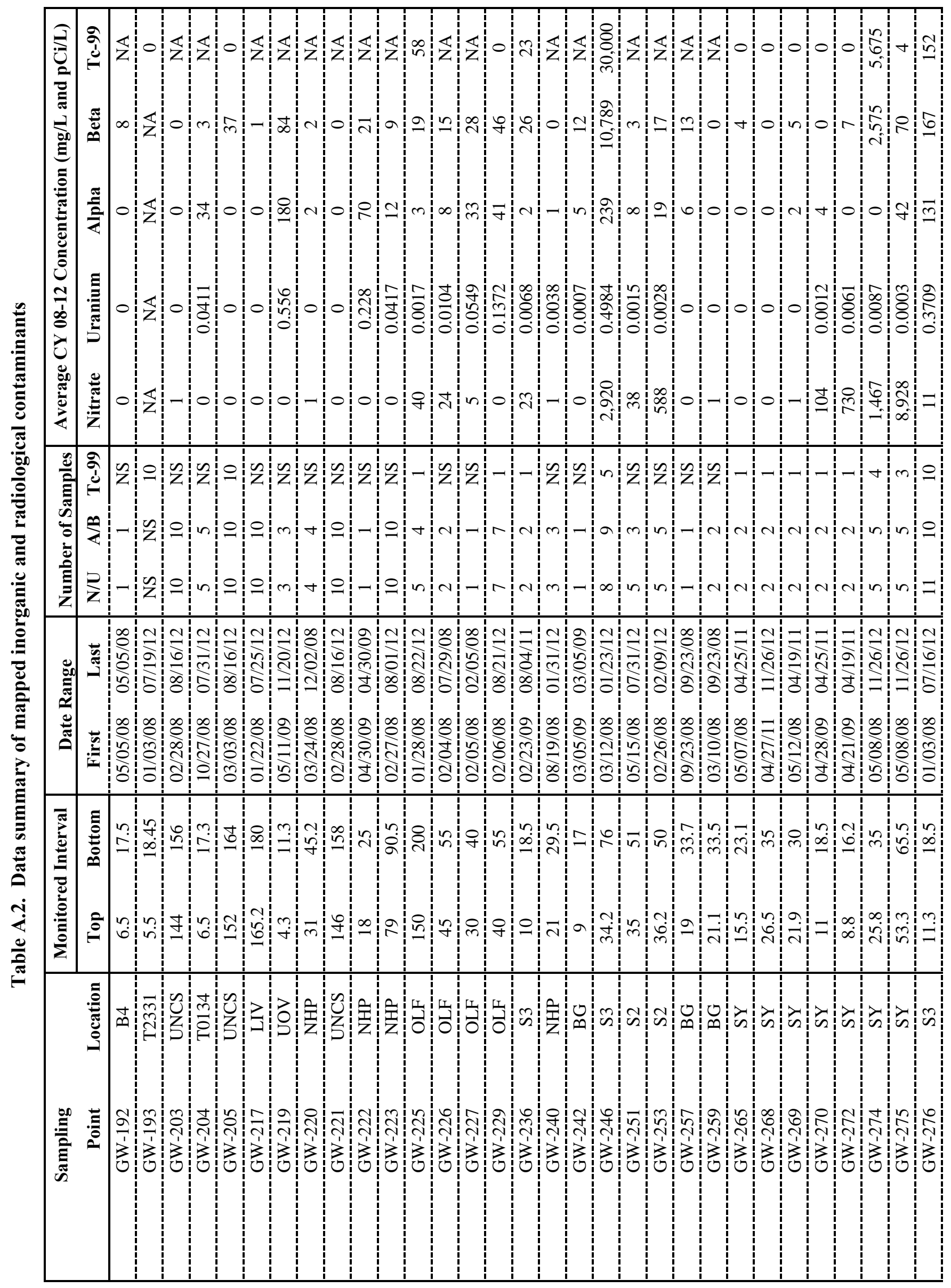




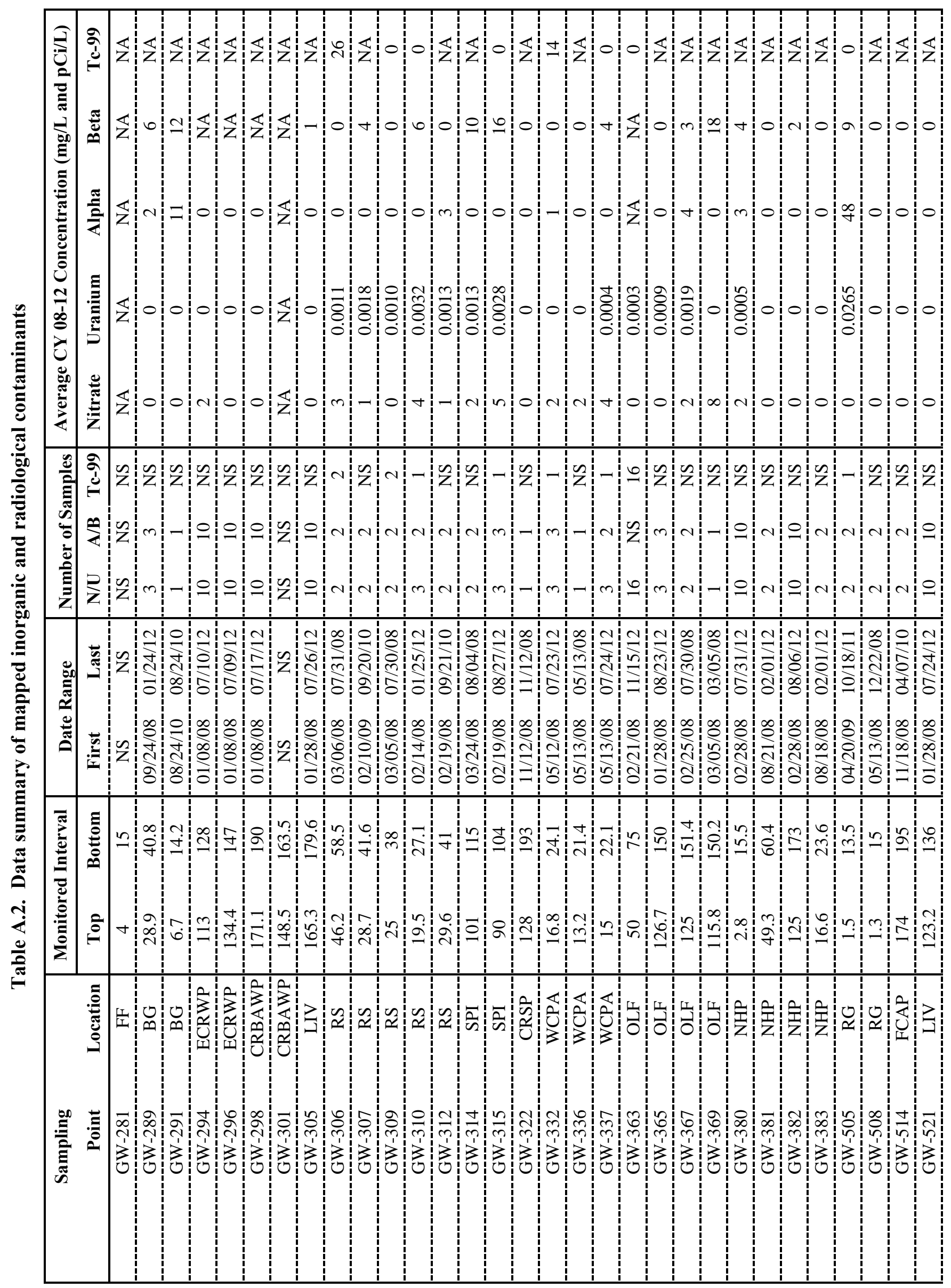




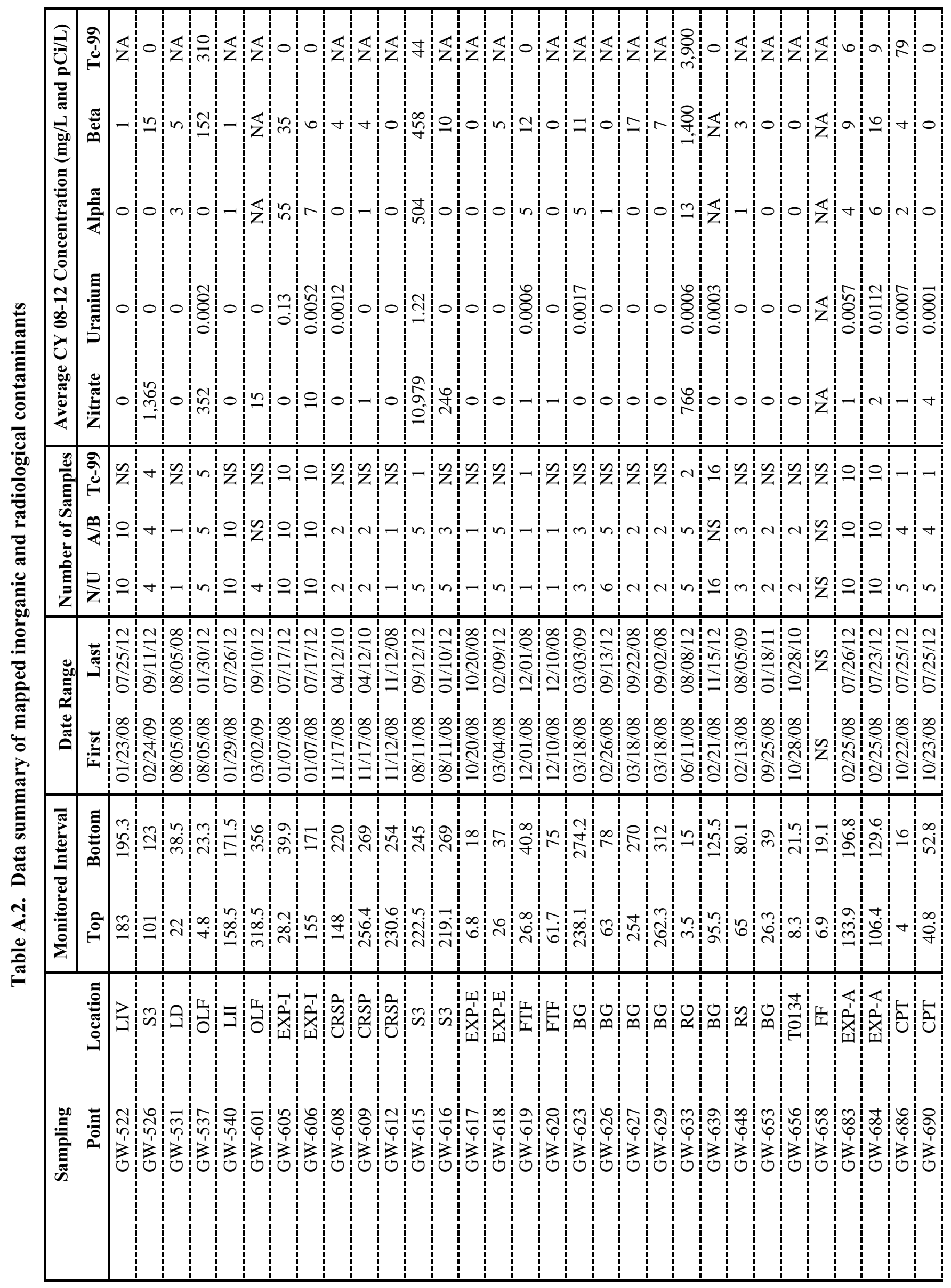




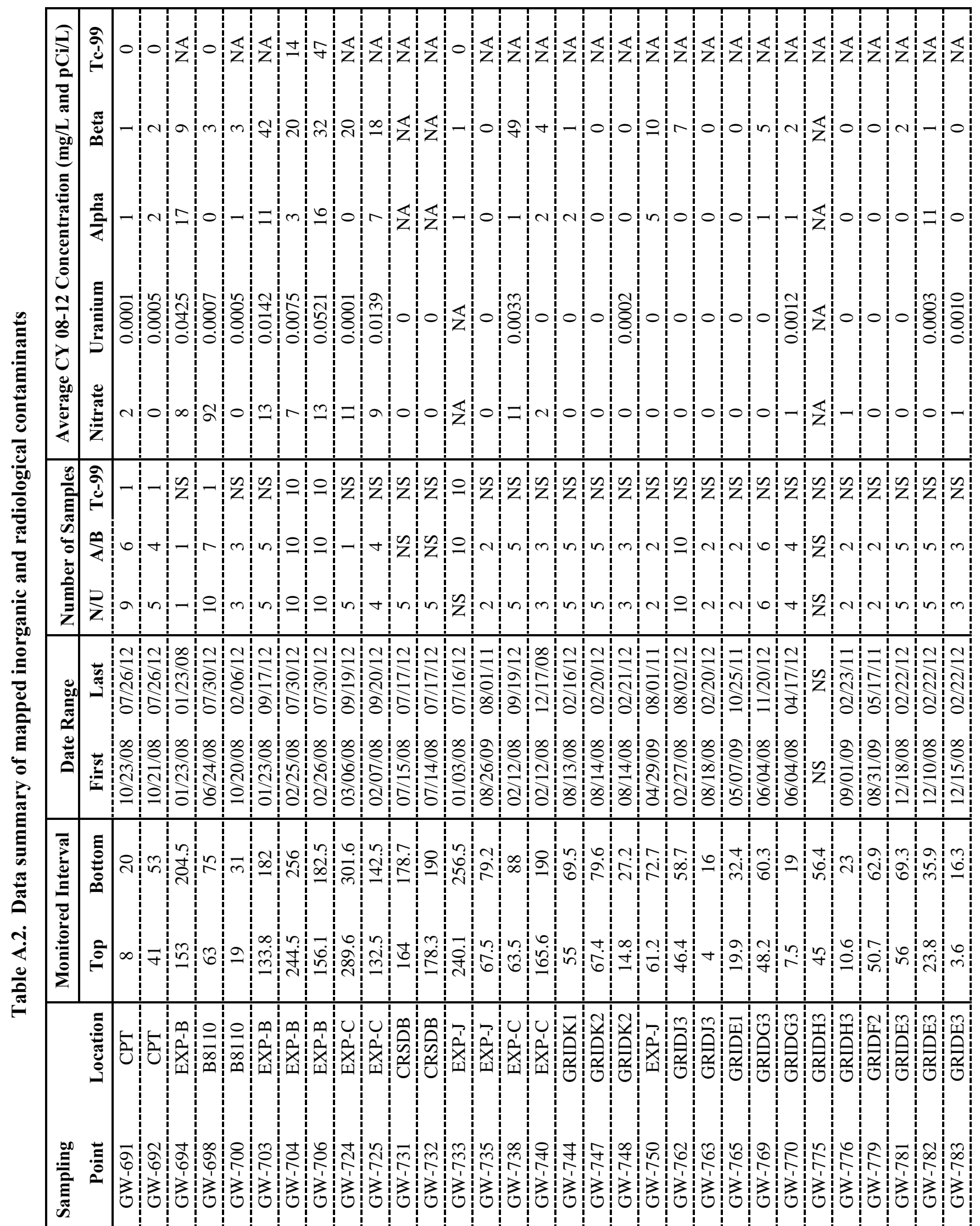

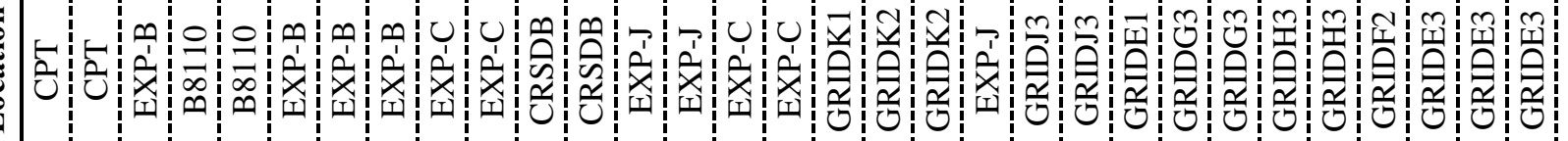

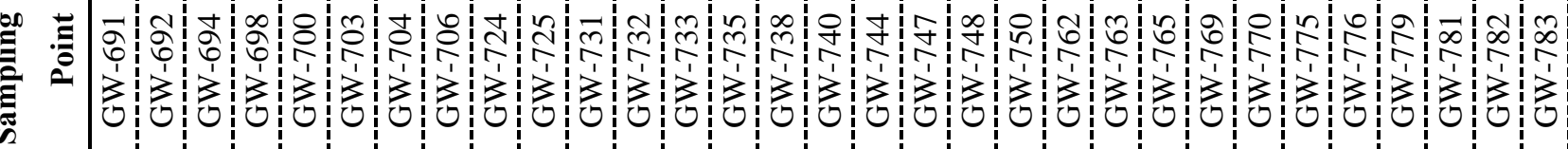




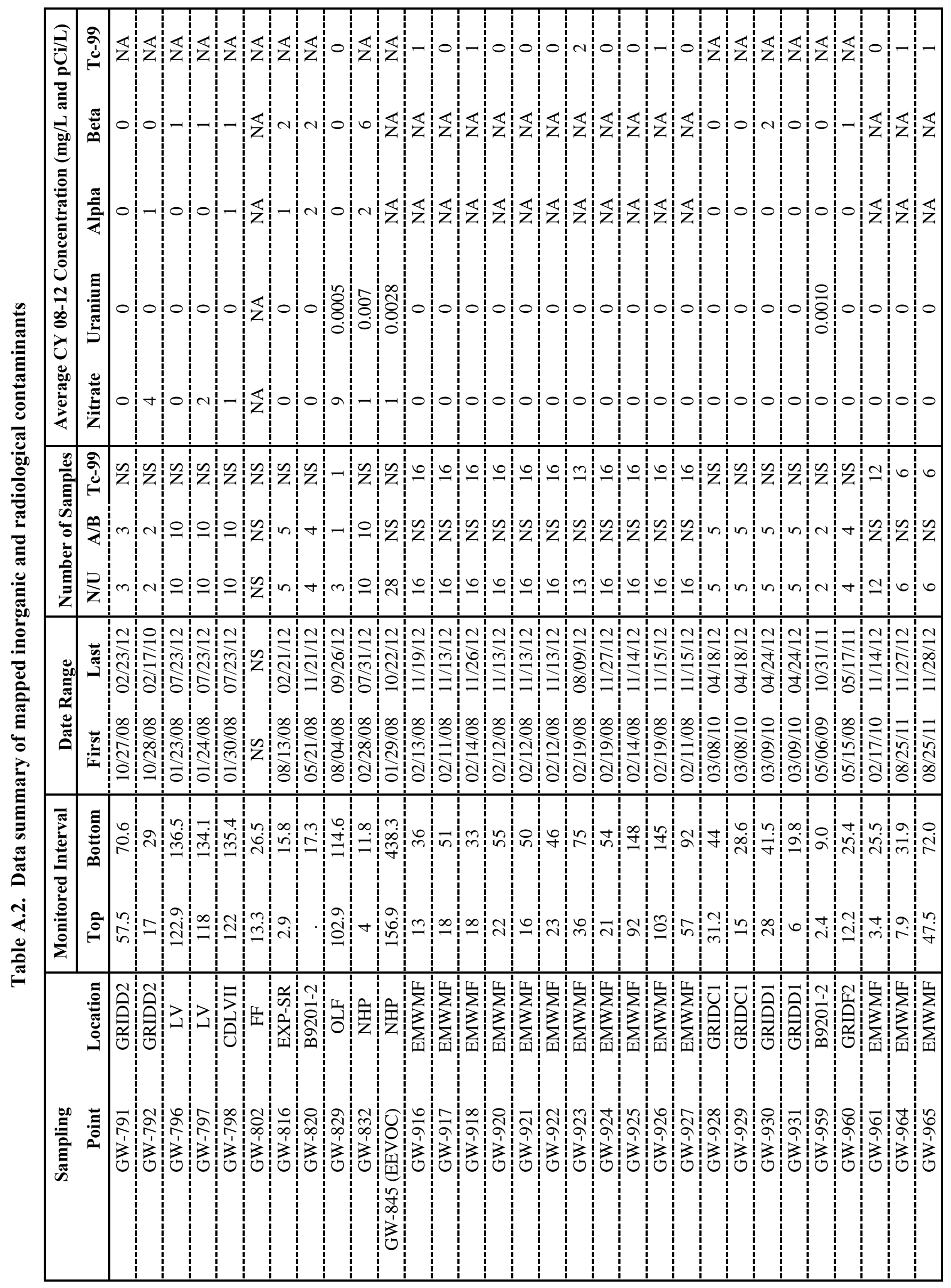




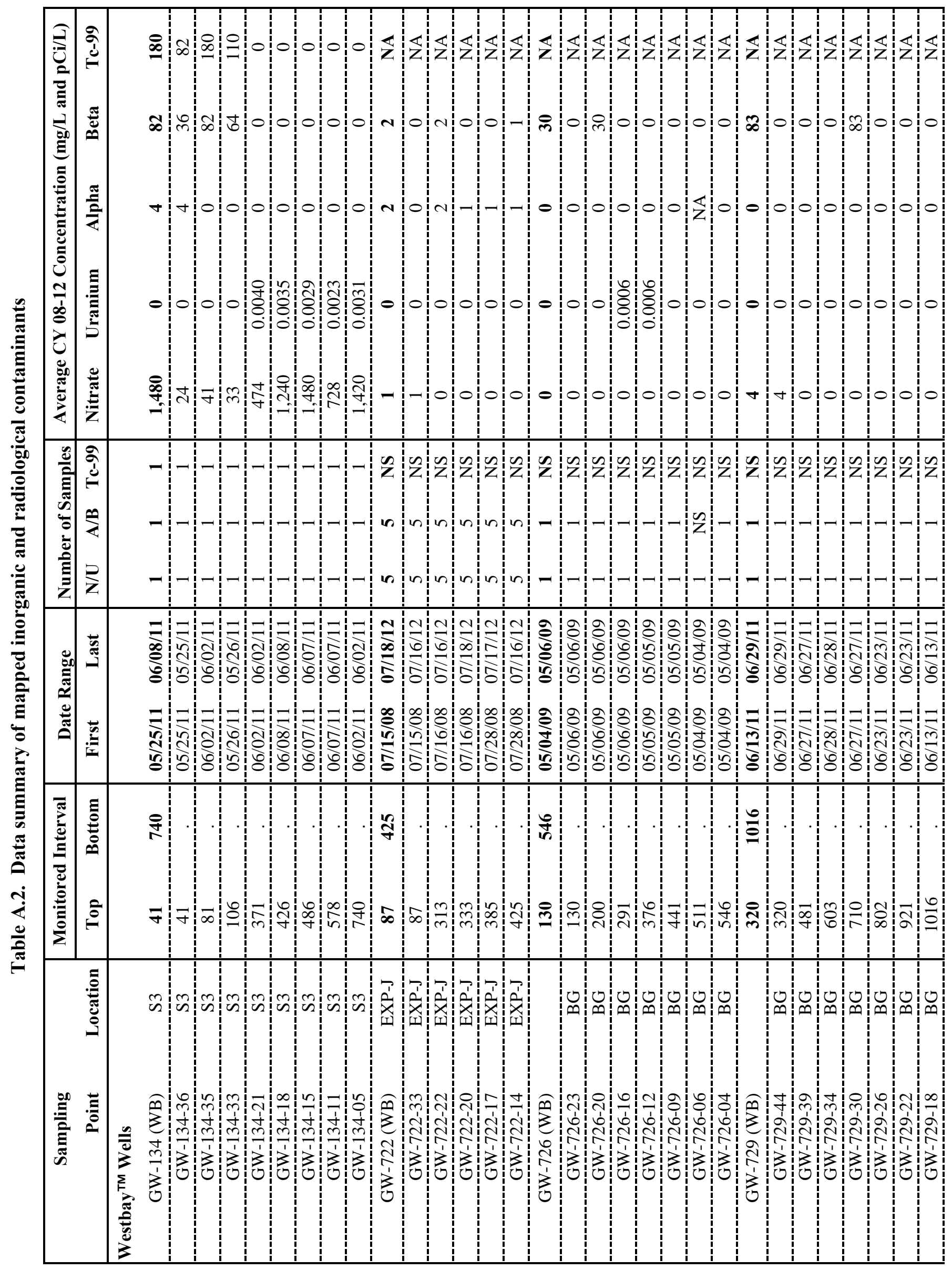




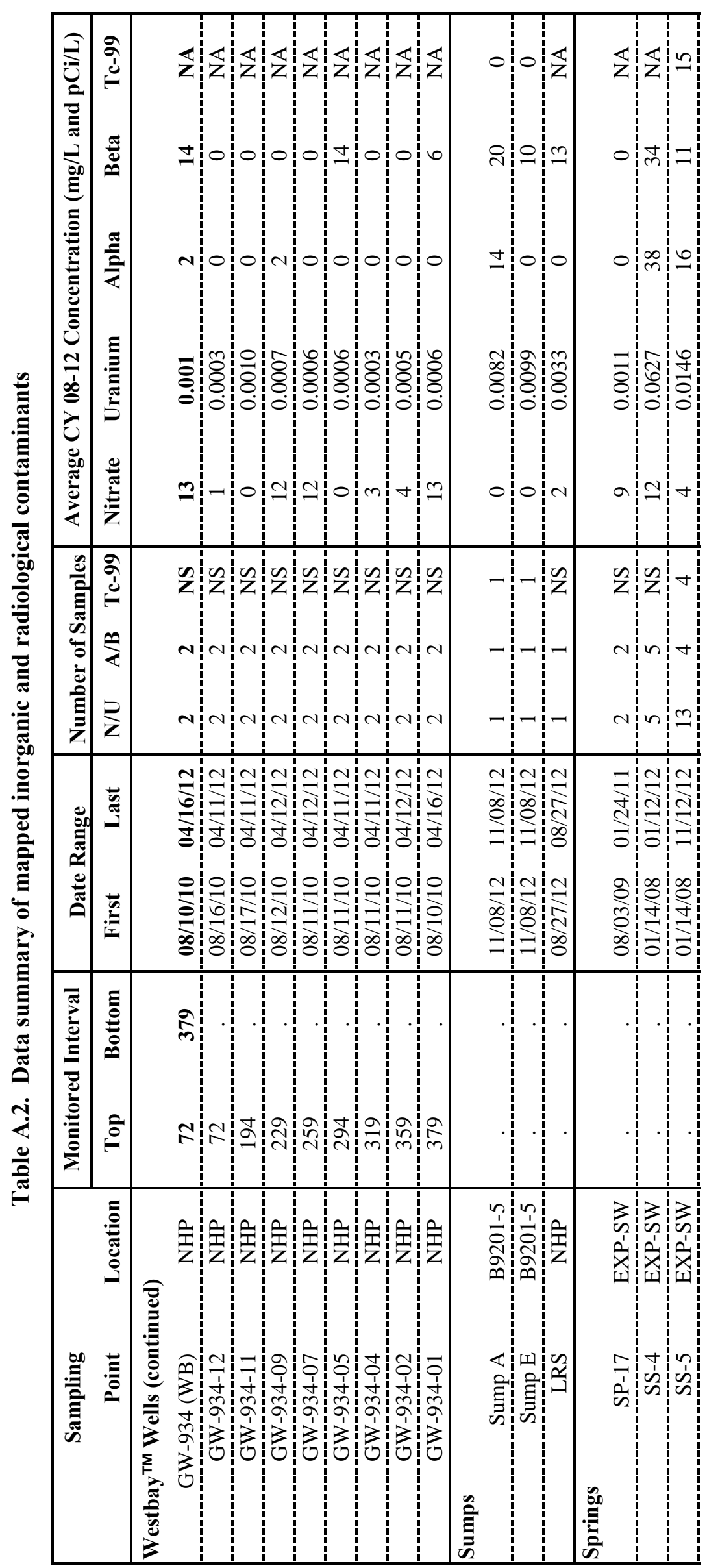


APPENDIX B

CONTAMINANT PLUME MAPS 
This page intentionally left blank. 


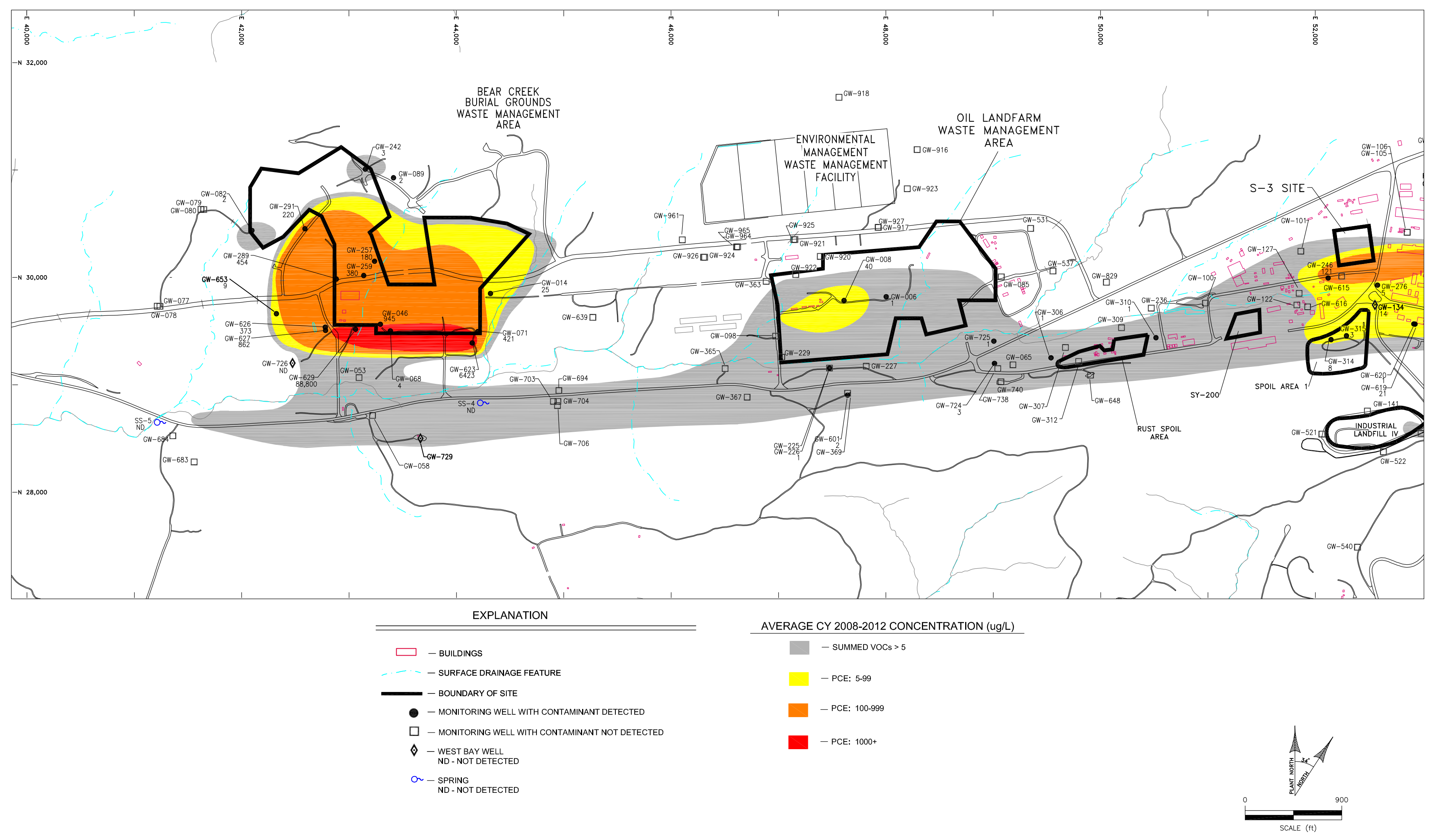




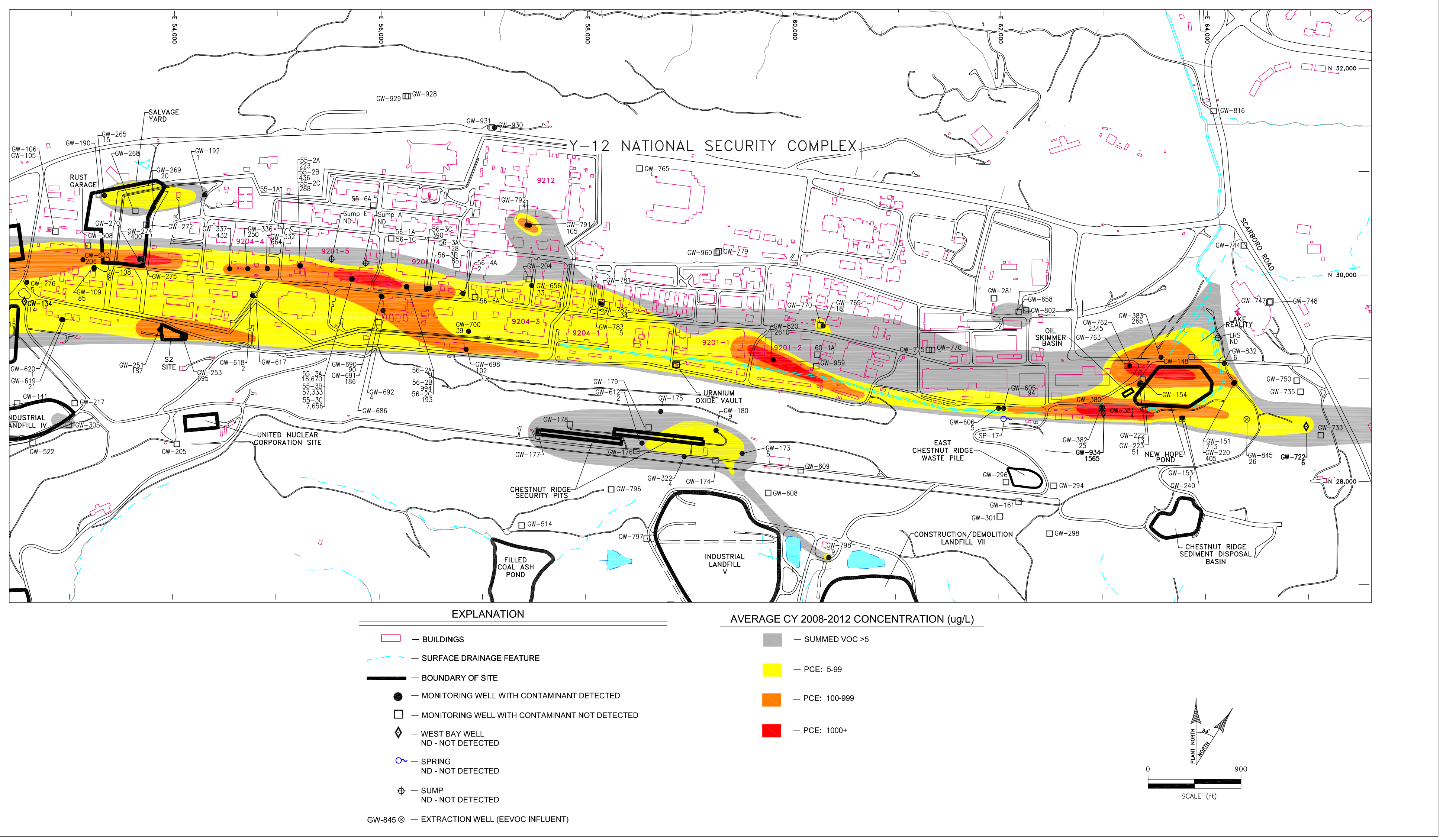




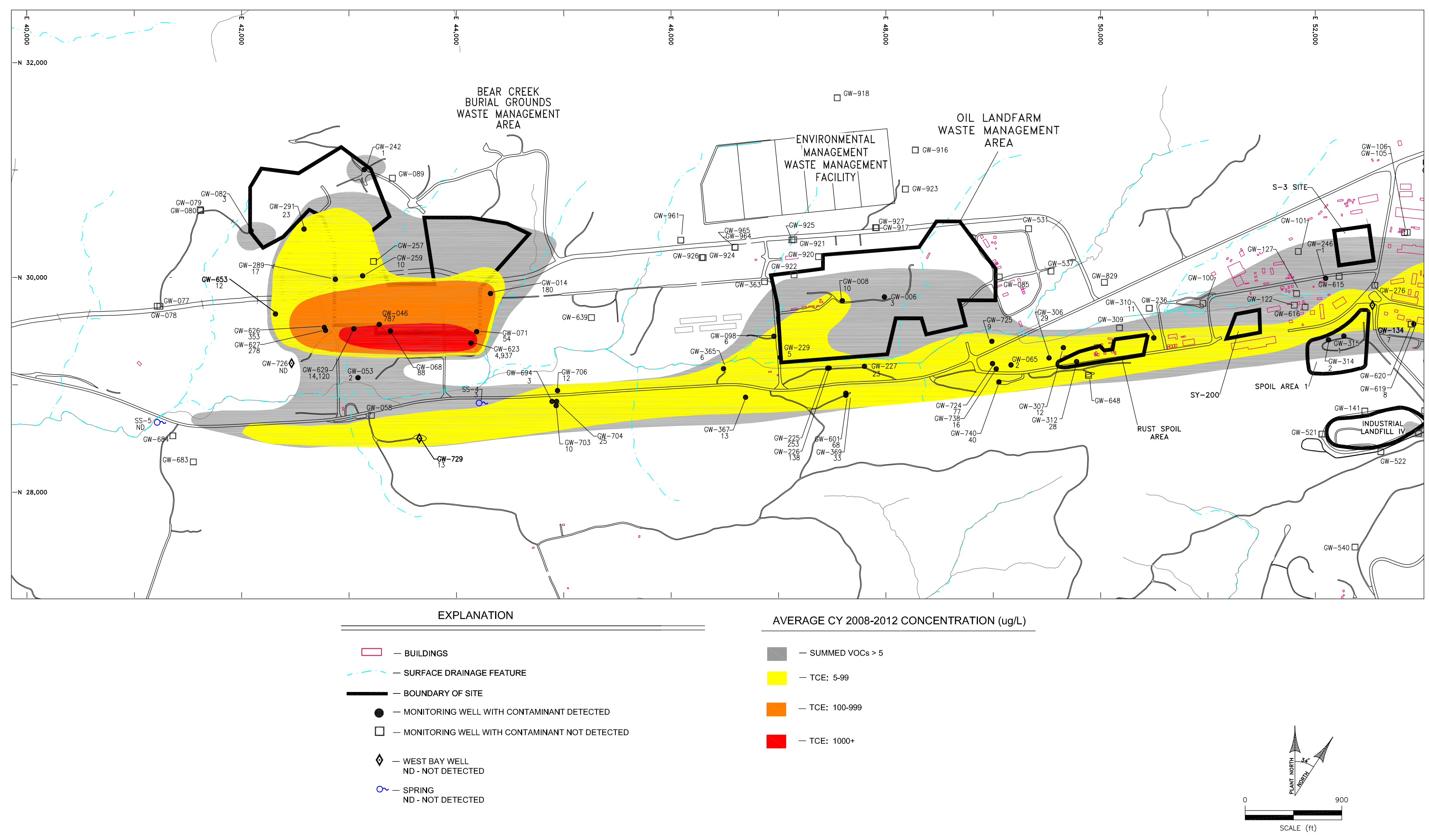




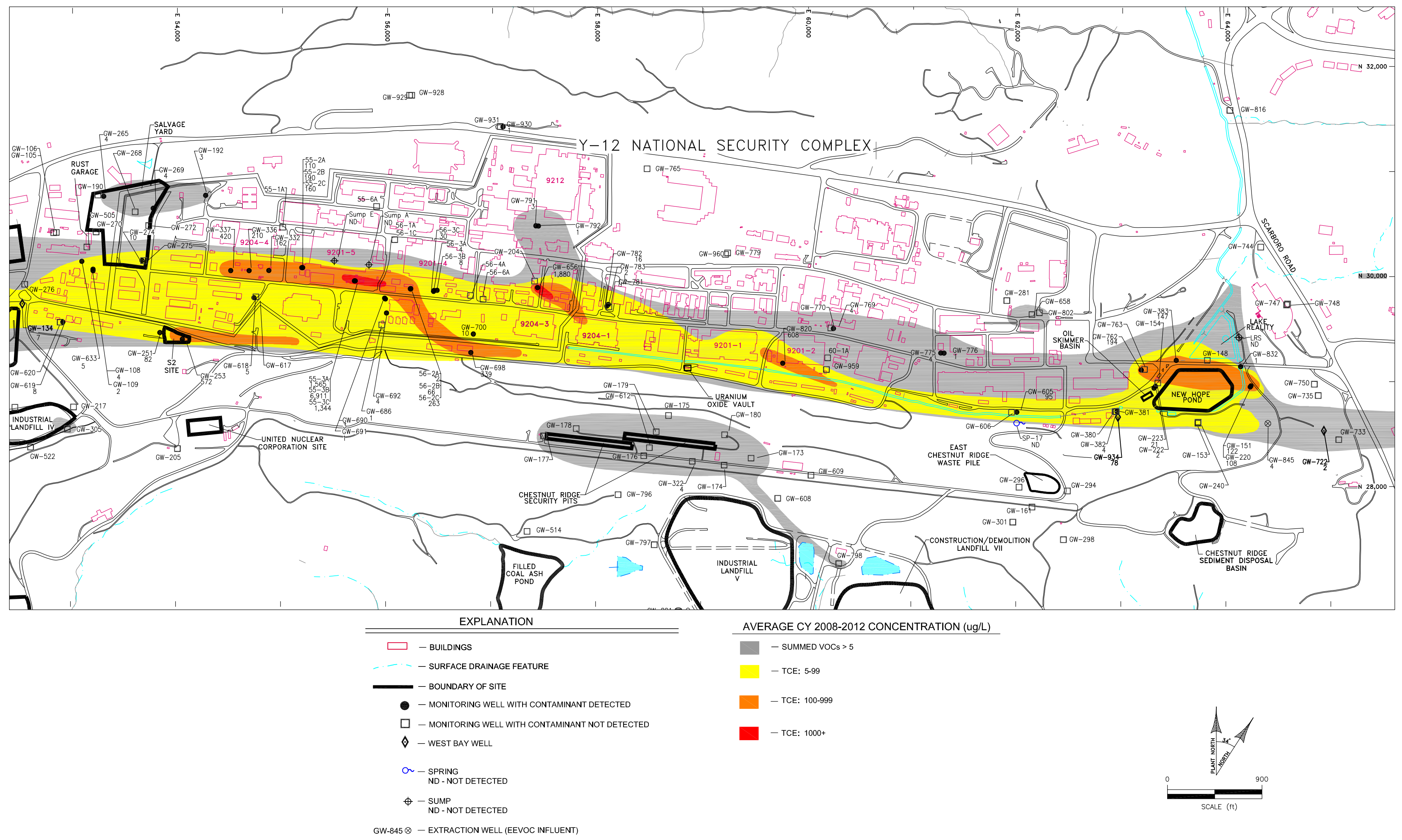




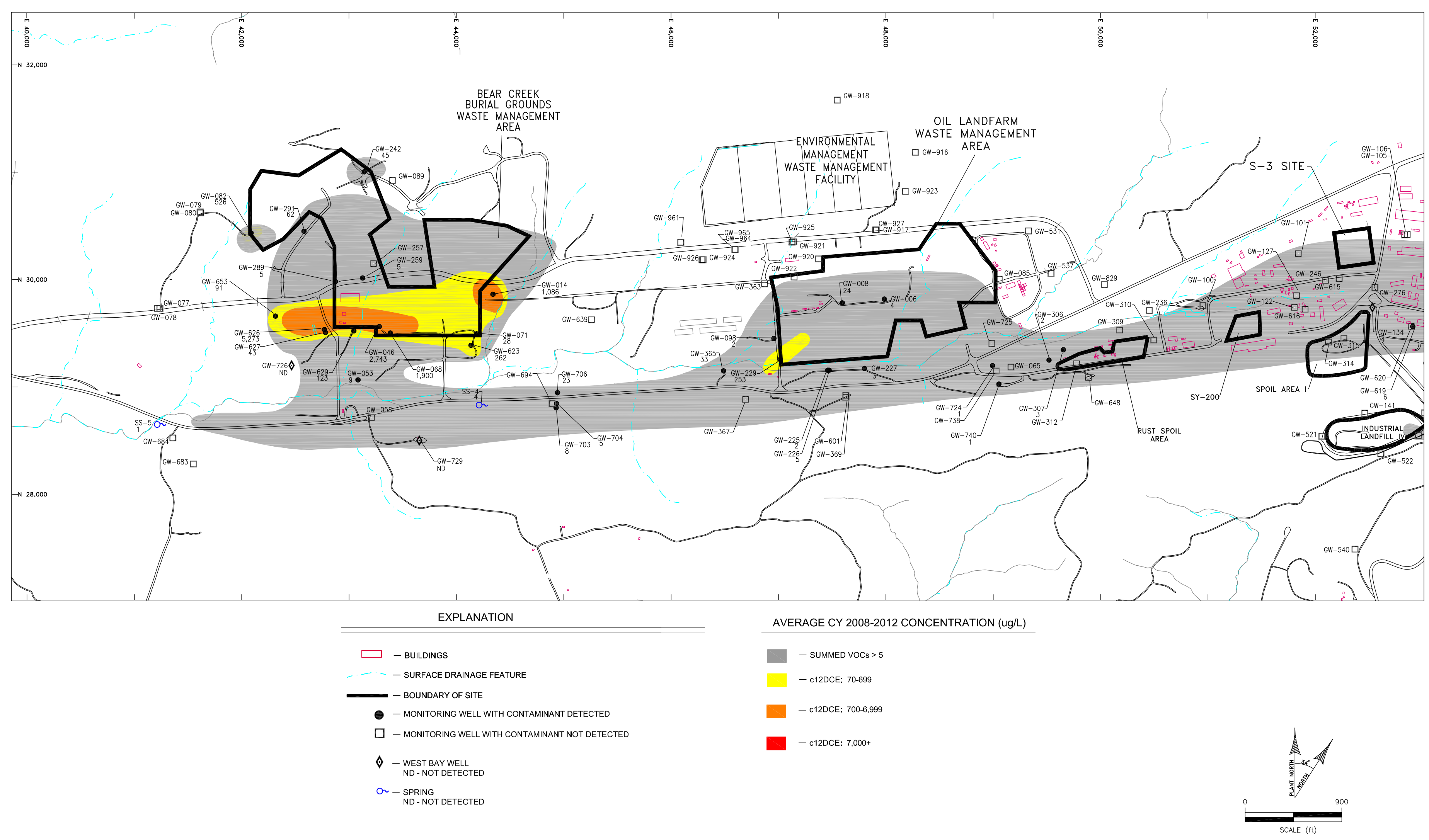




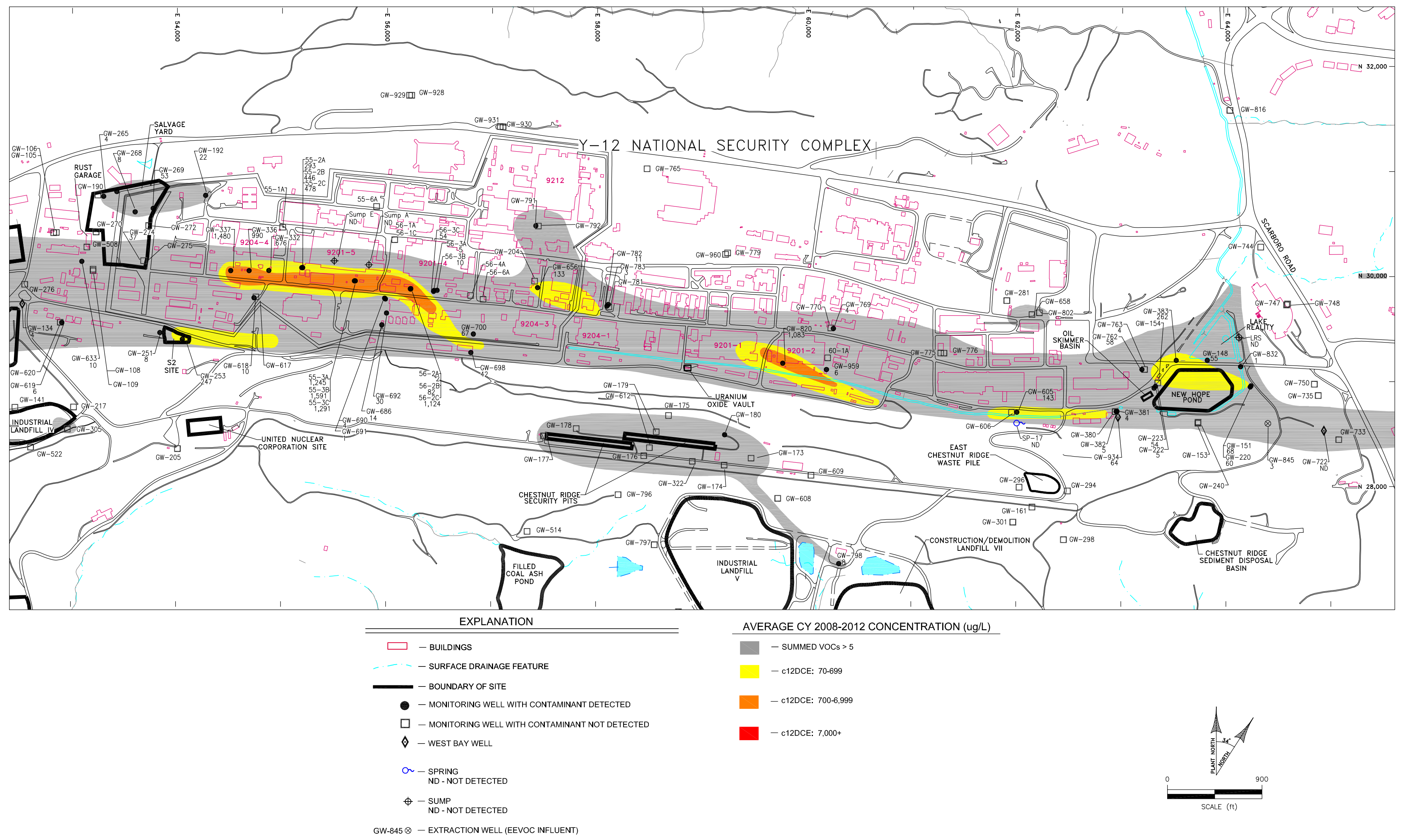




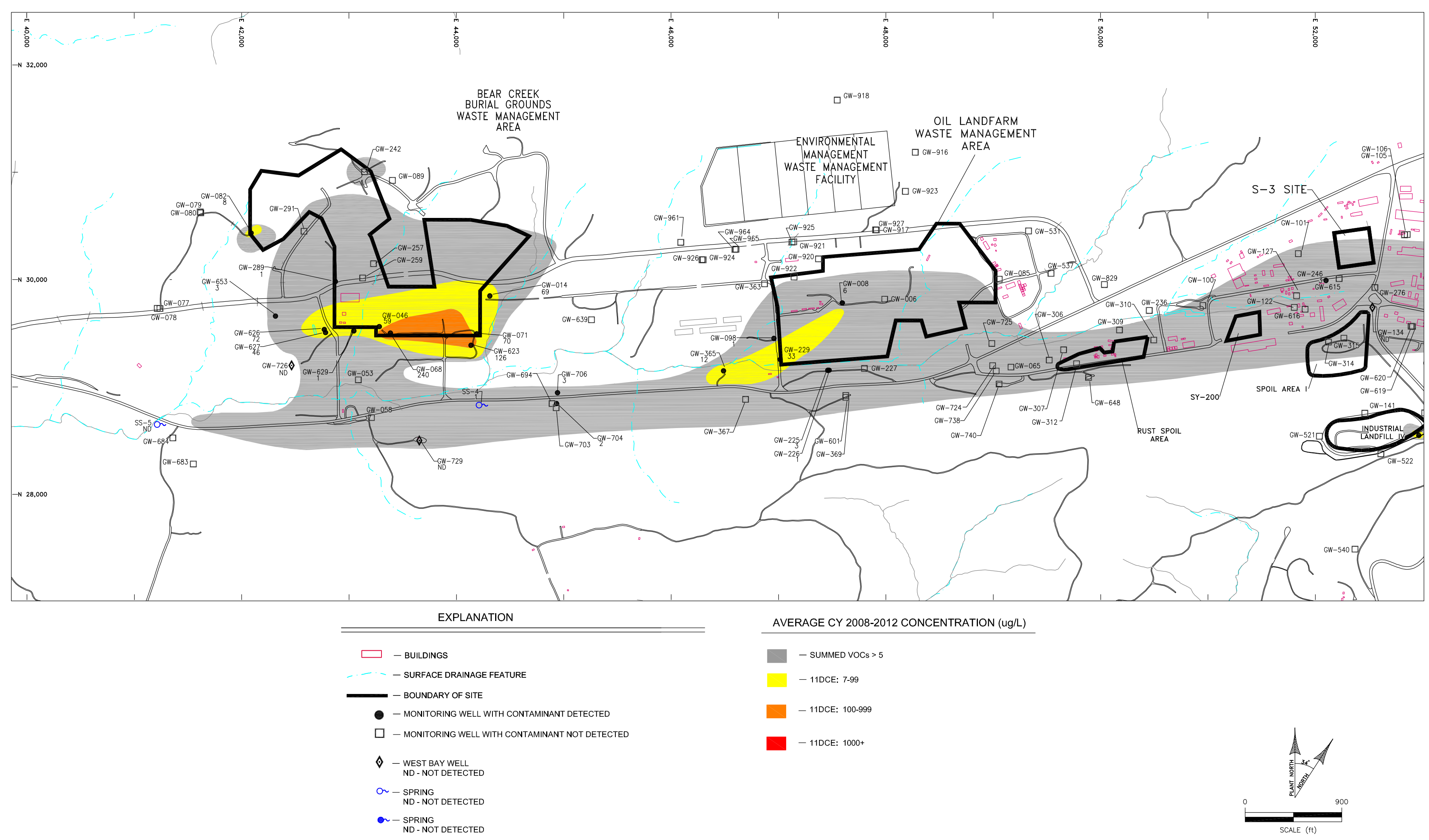




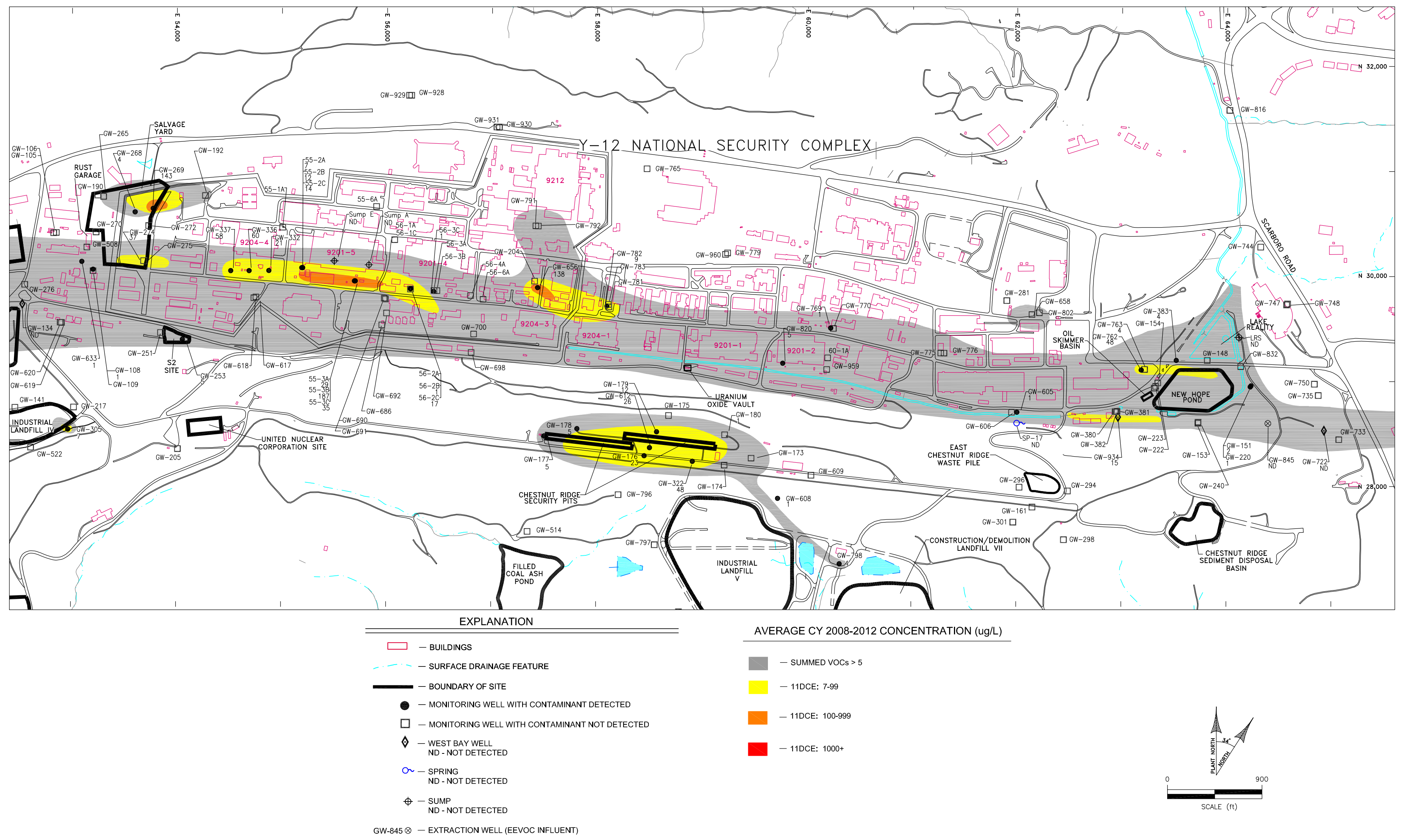




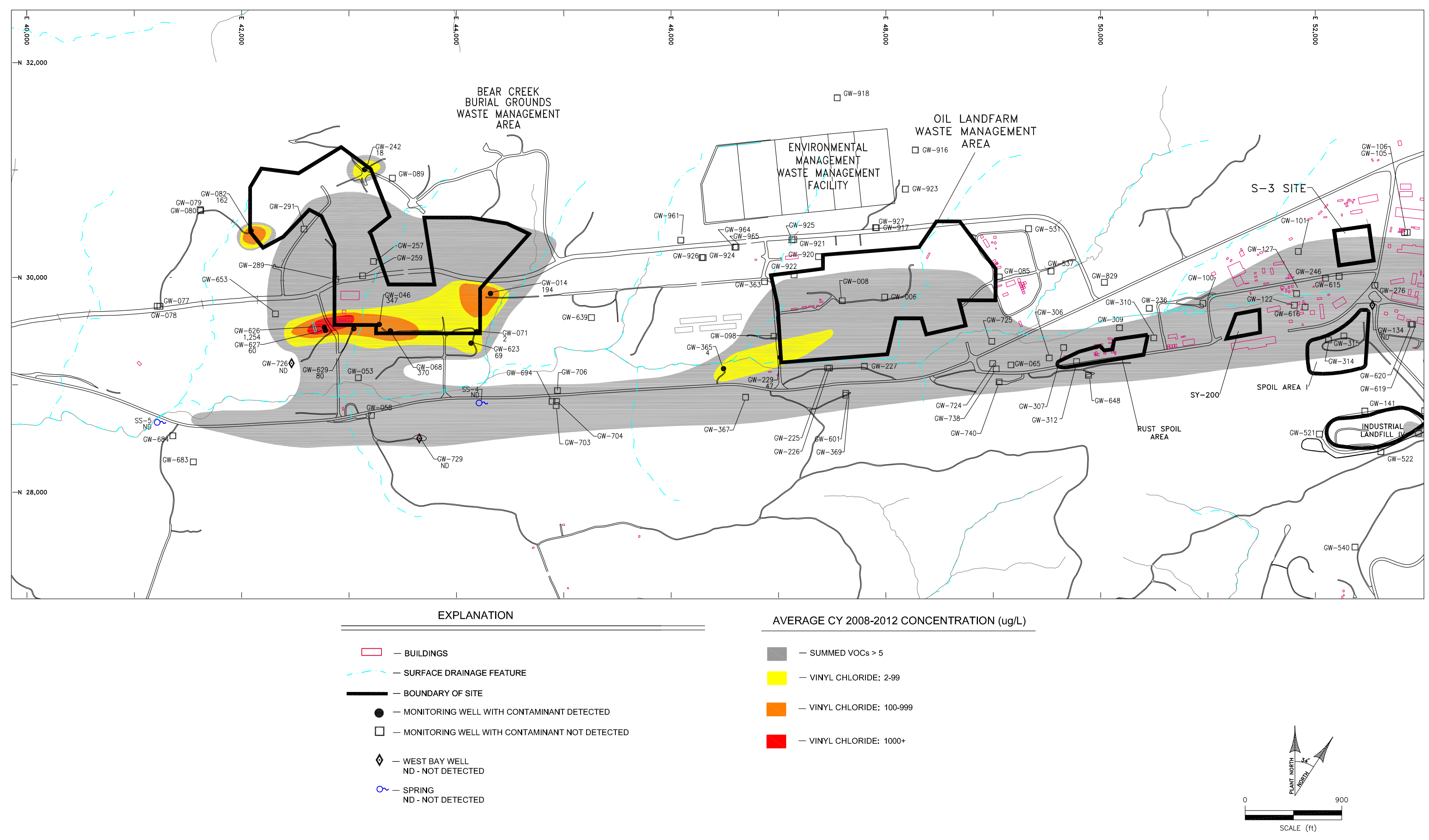




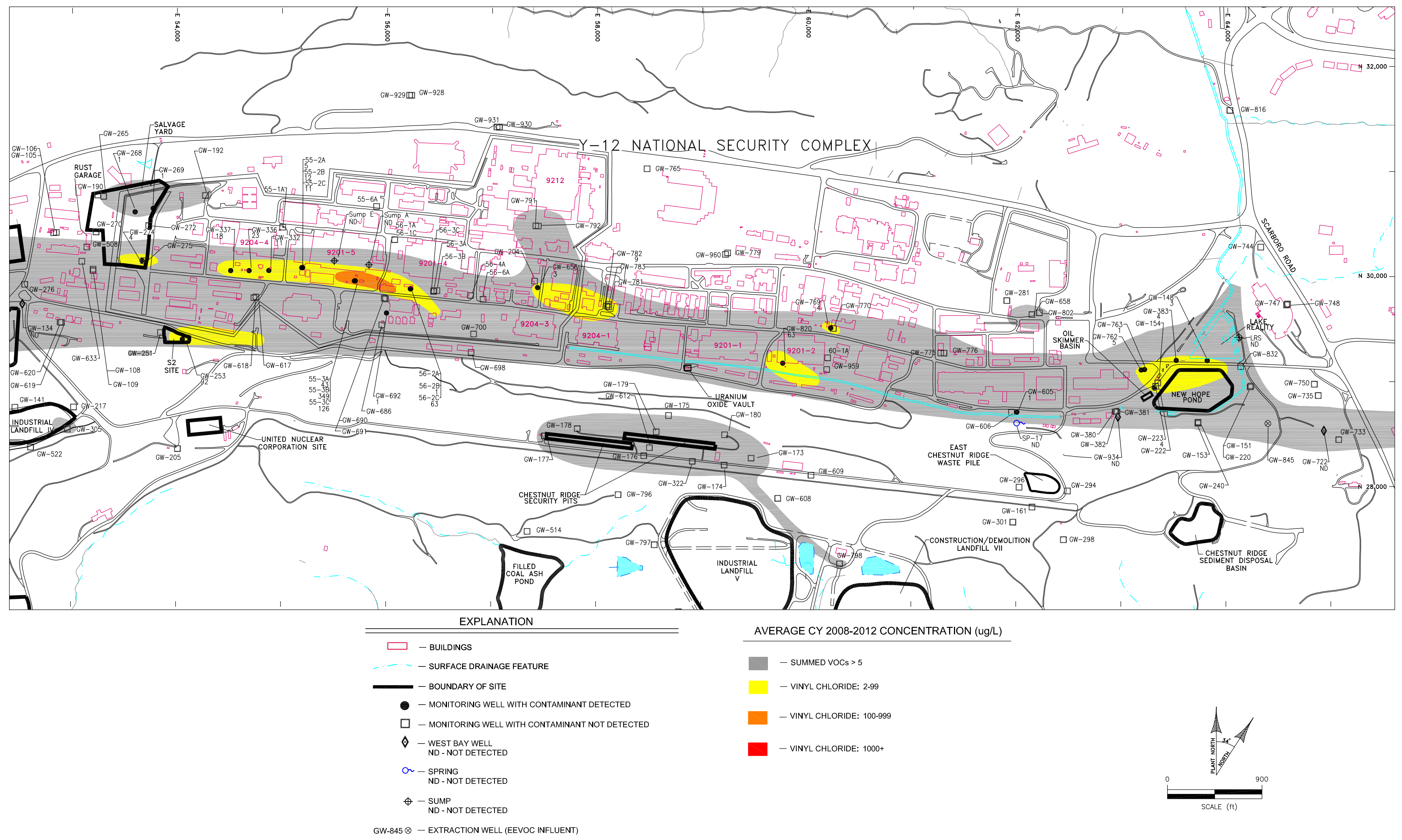




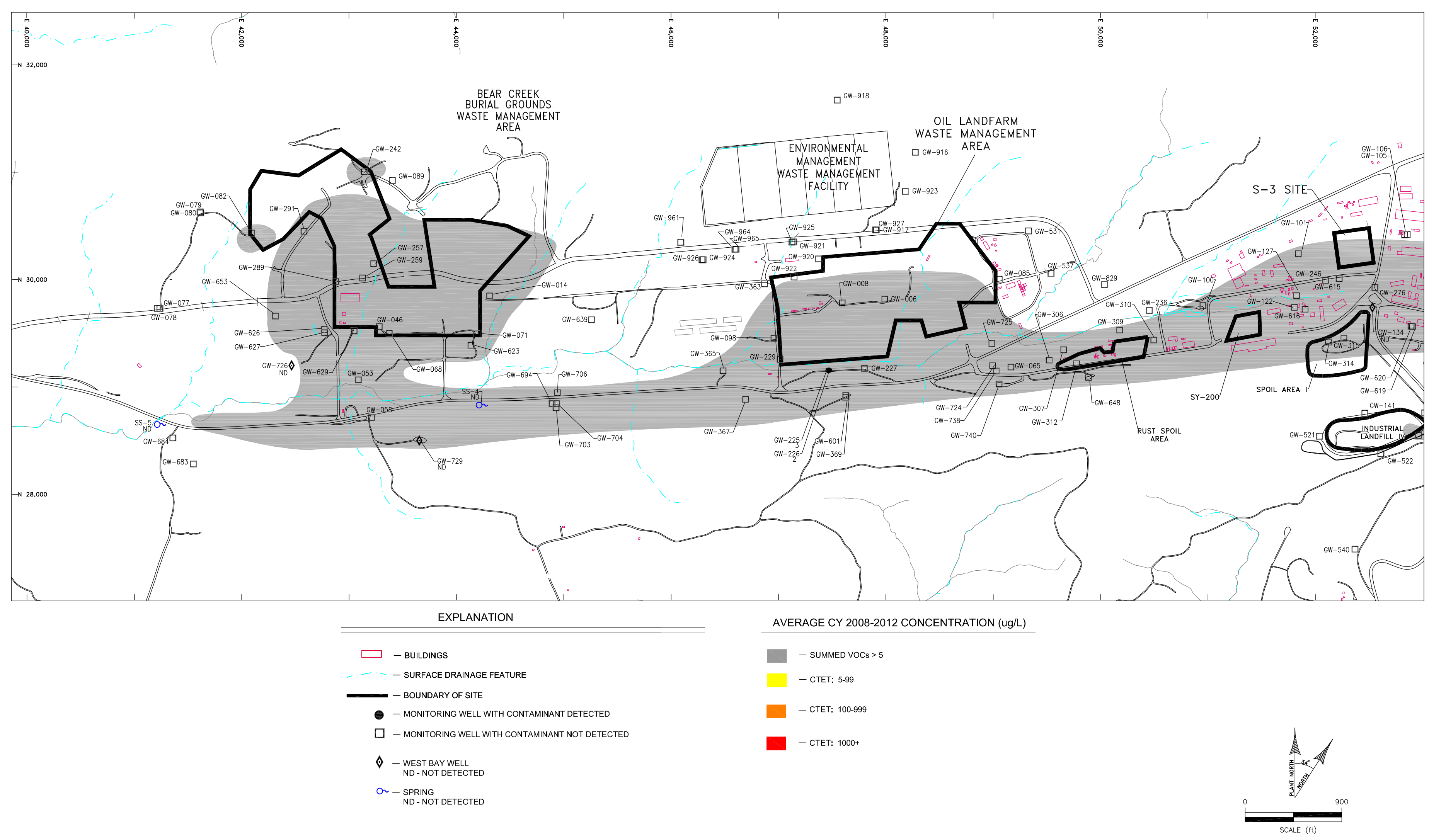




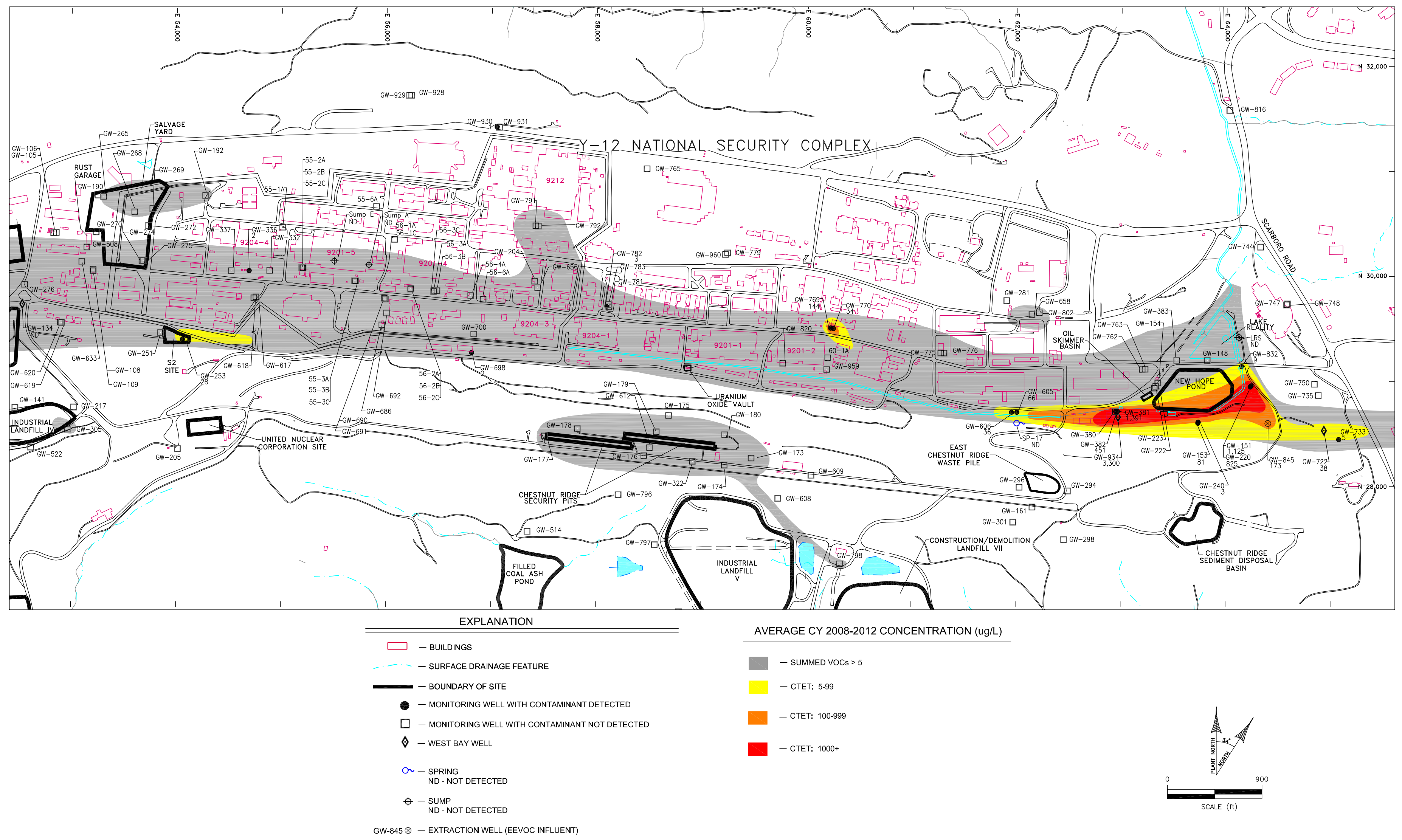




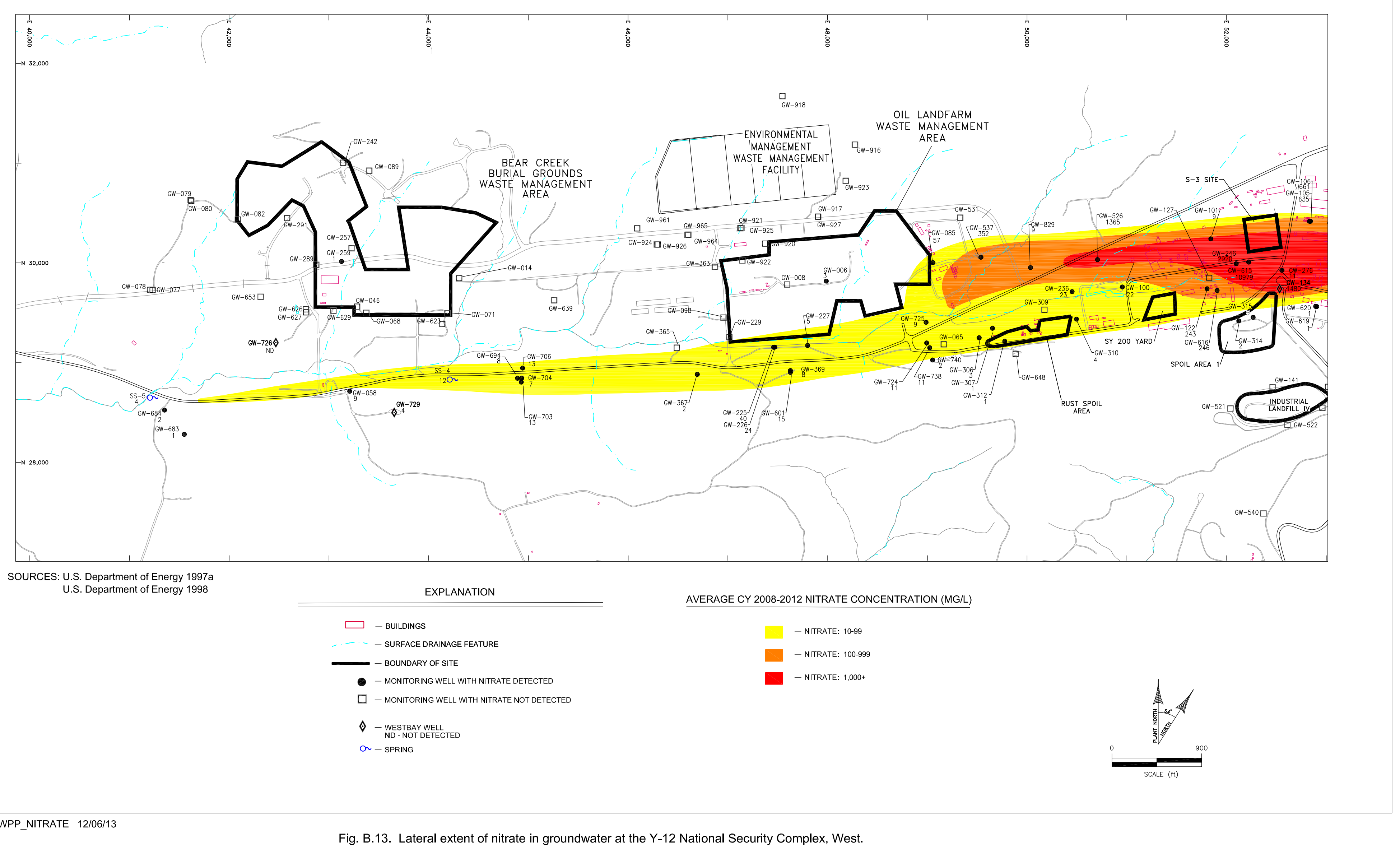




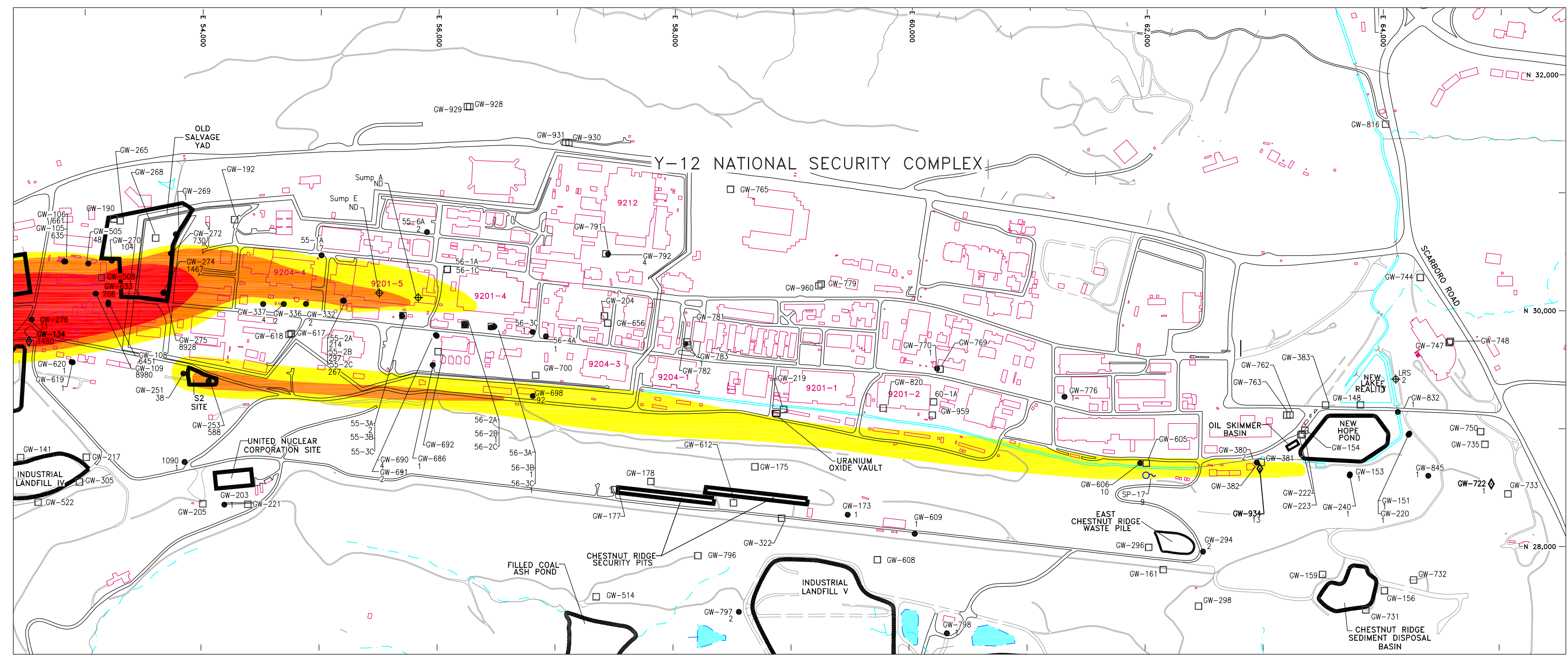
SOURCES: U.S. Department of Energy 1997a
U.S. Department of Energy 1998

EXPLANATION

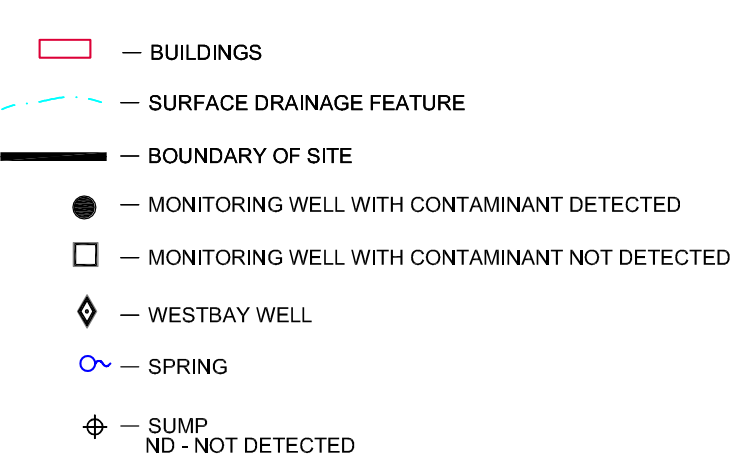

AVERAGE CY 2008-2012 NITRATE CONCENTRATION (MG/L)

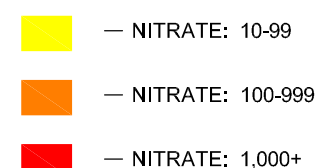

- NITRATE: $1,000+$

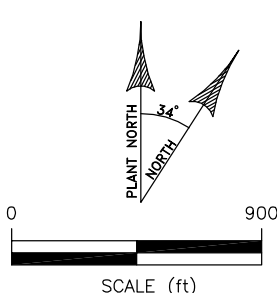




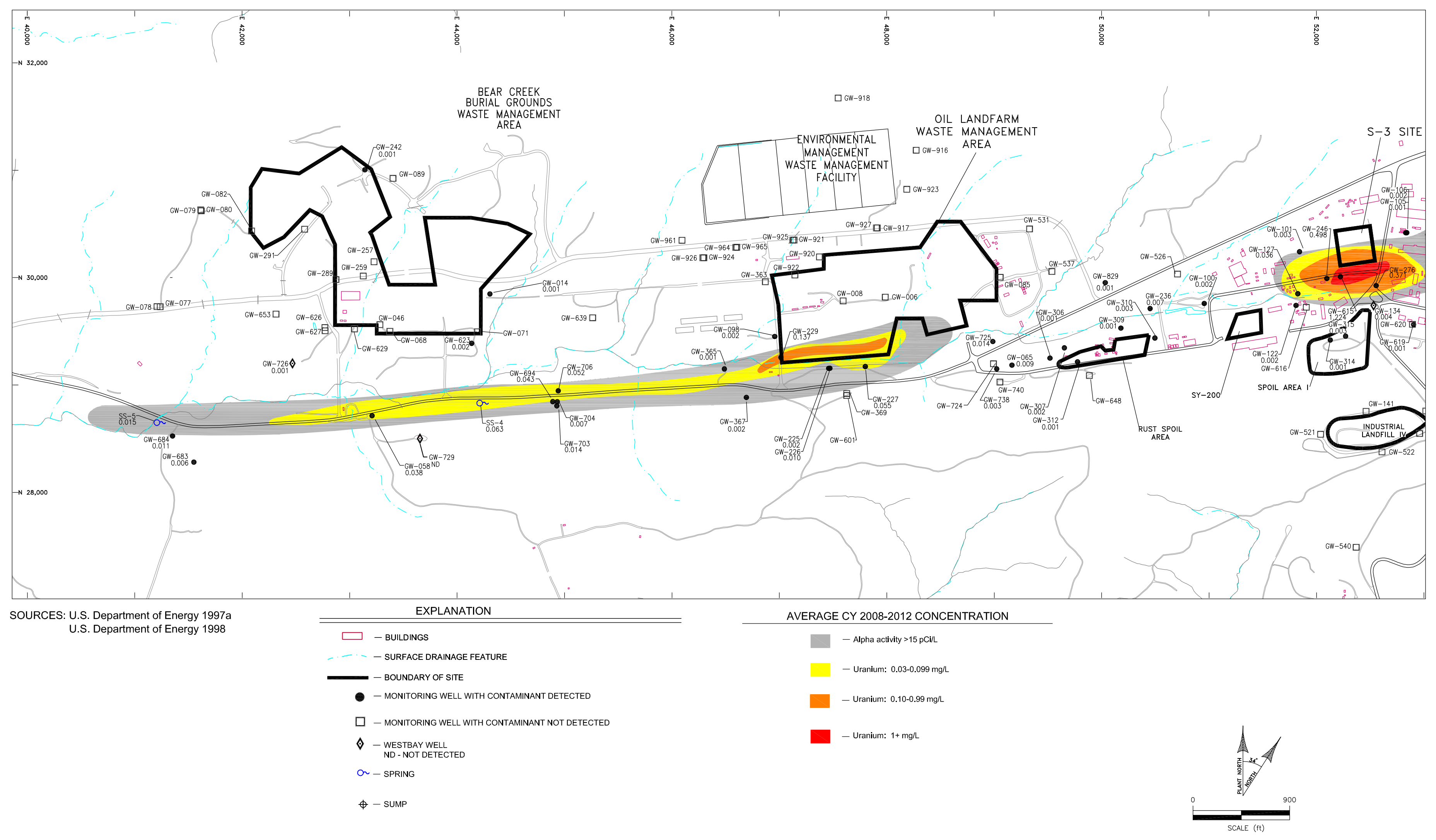




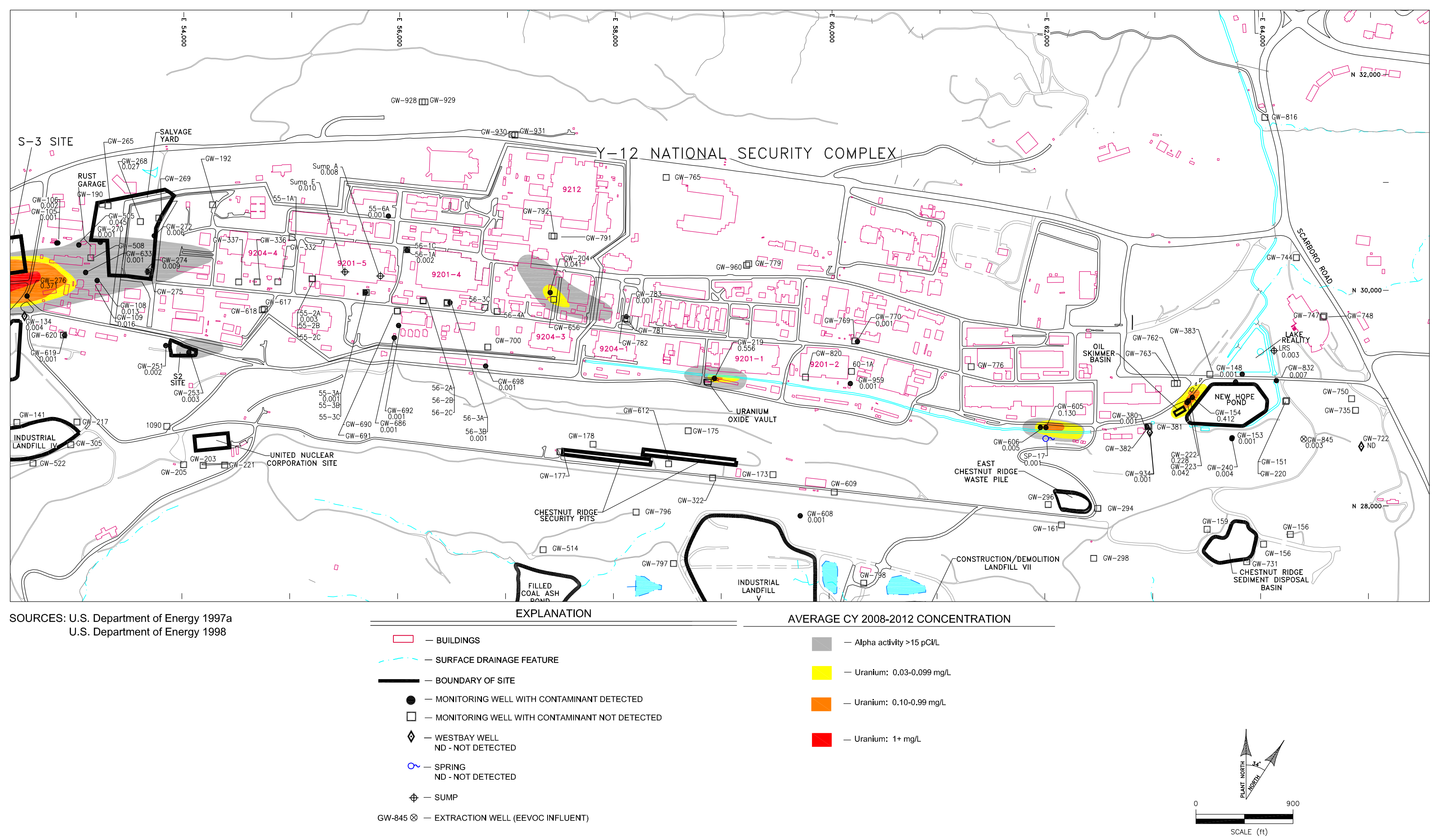




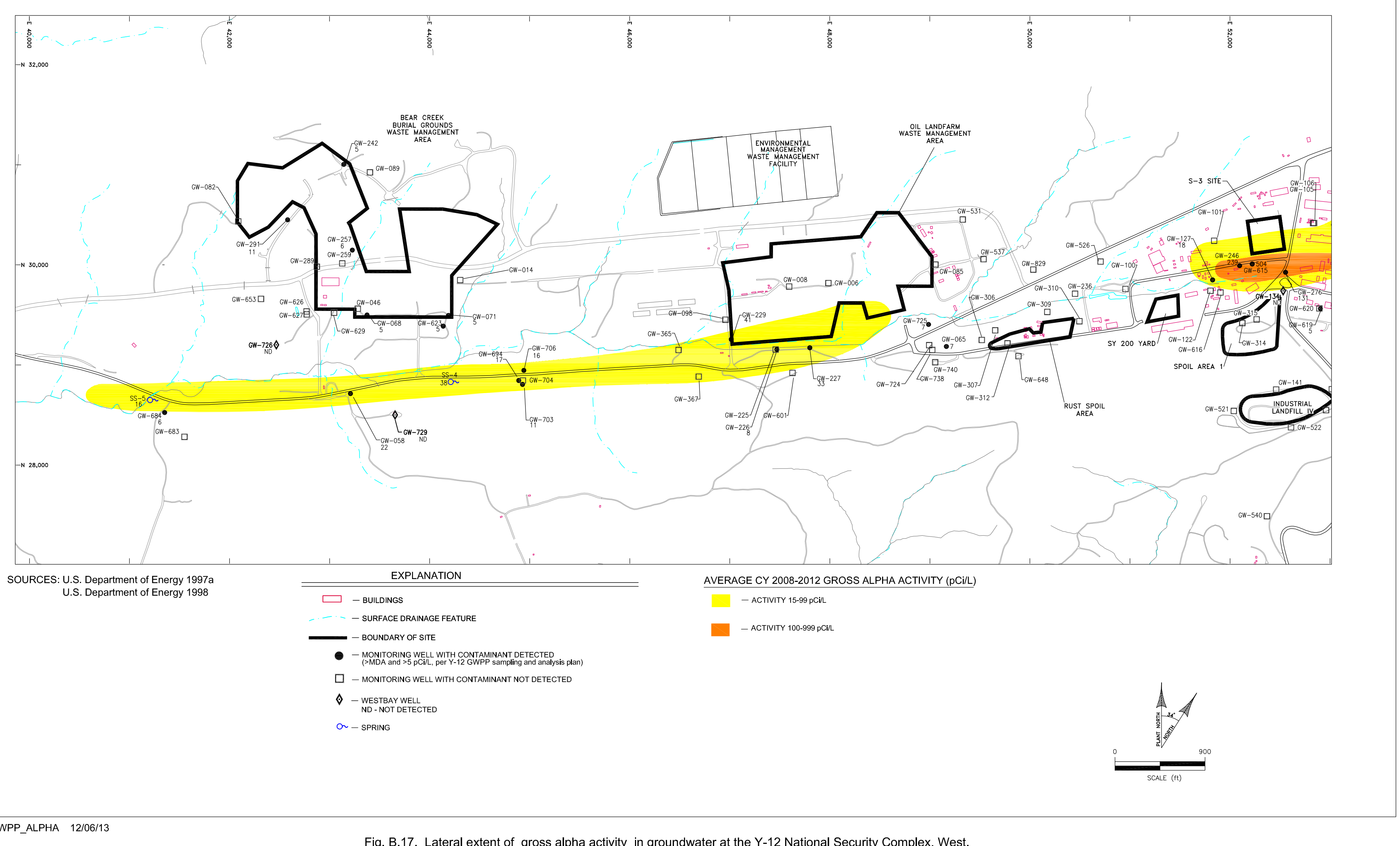




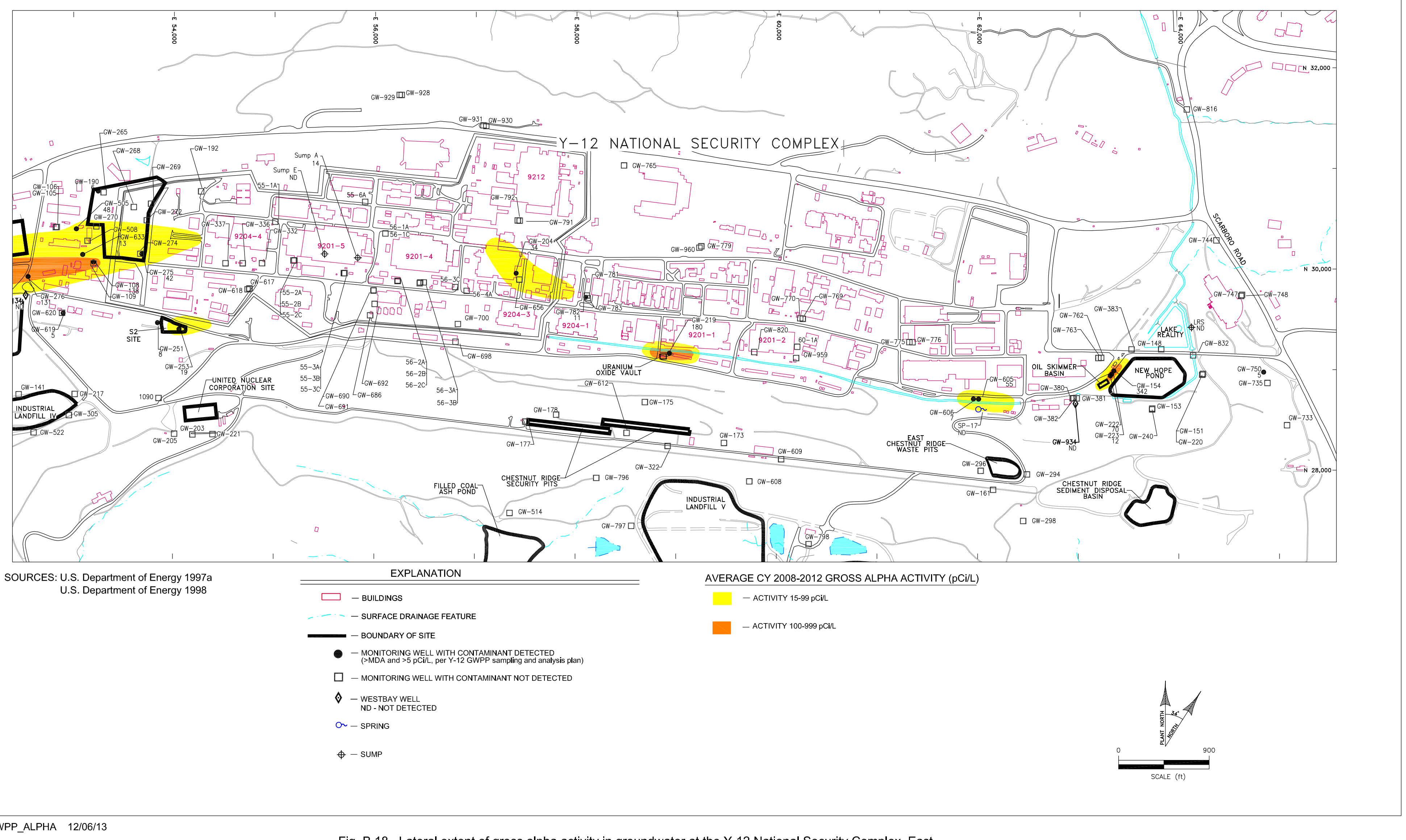




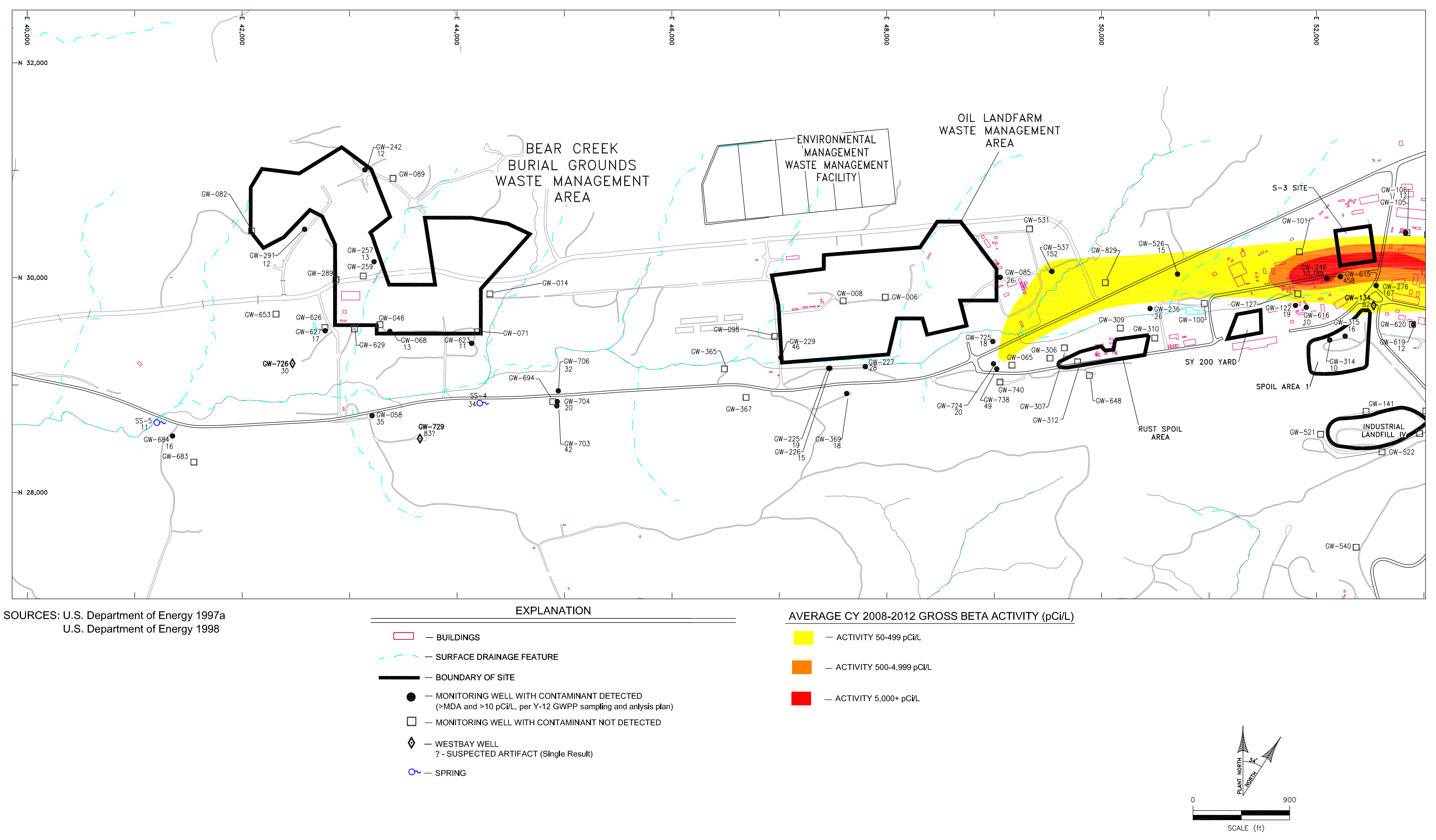




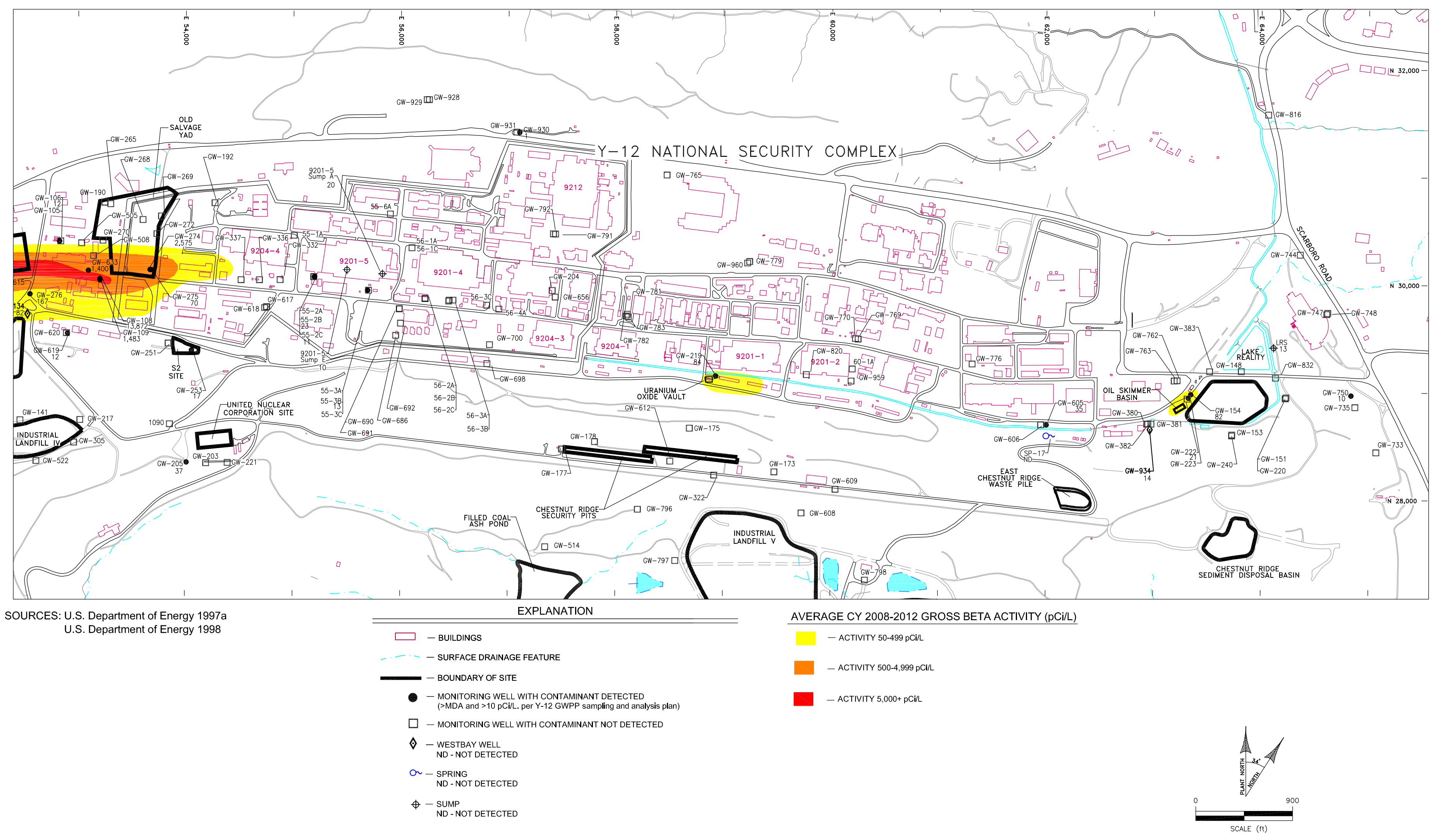




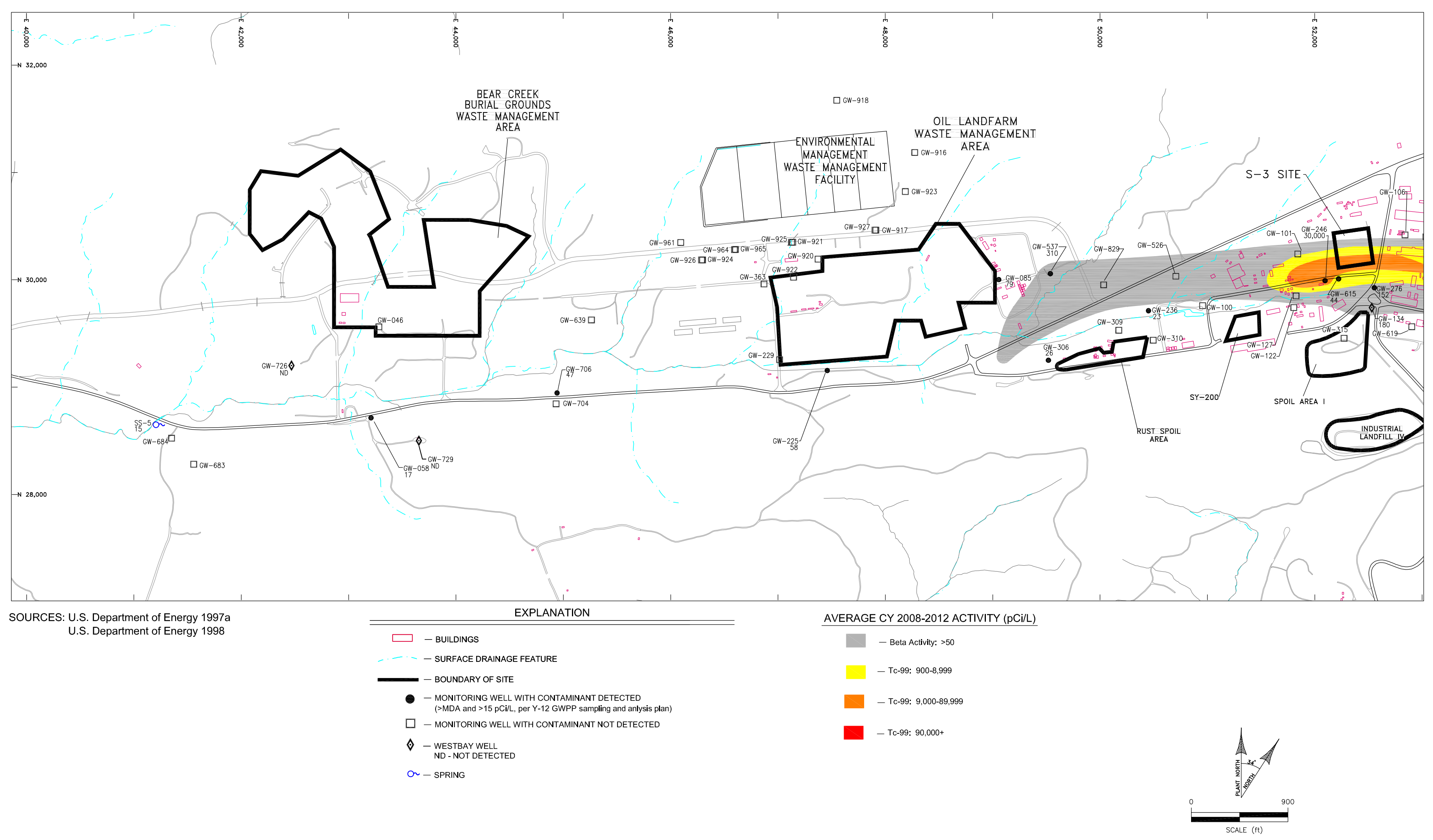




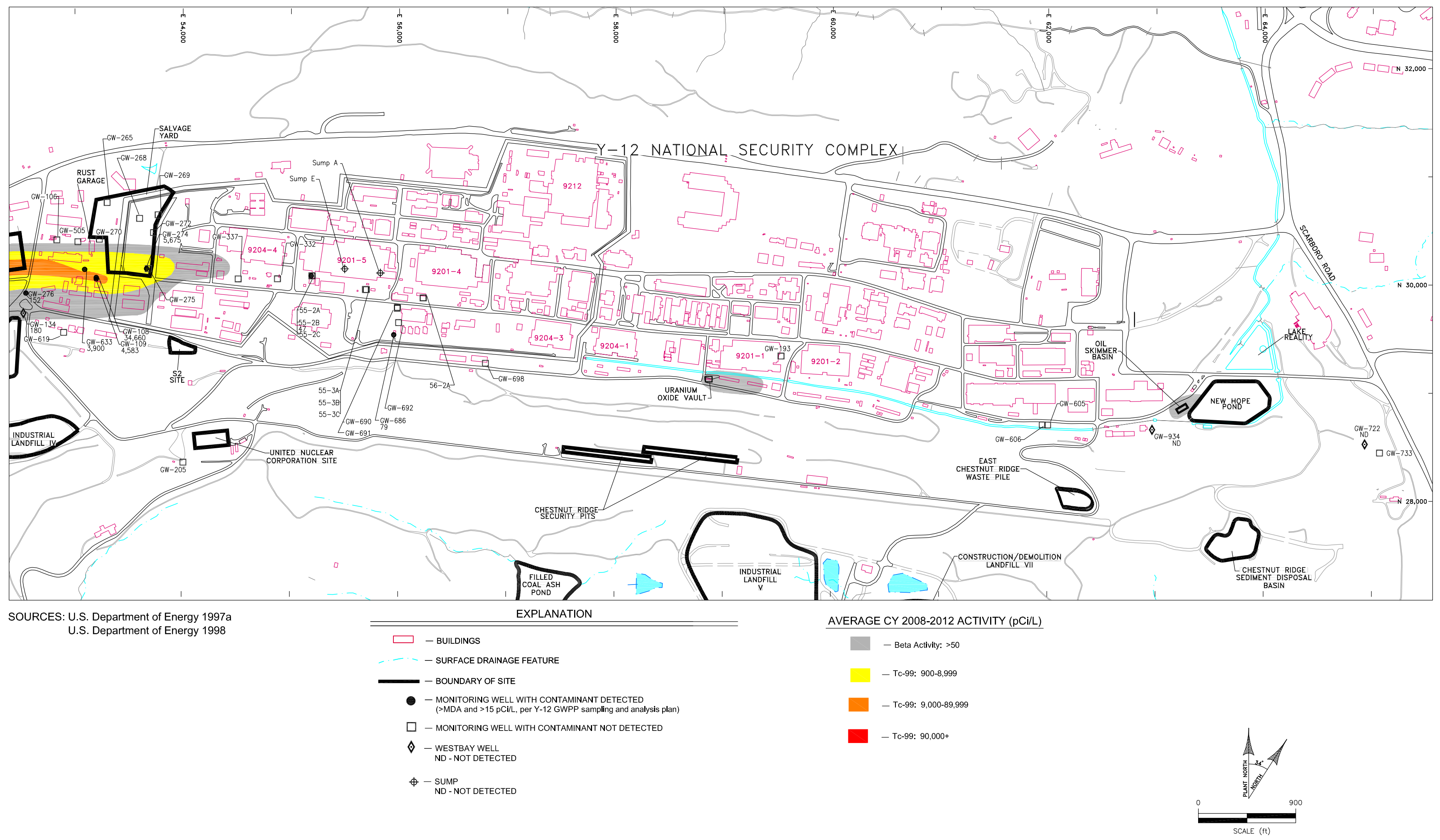





\section{DISTRIBUTION}

\section{U.S. DEPARTMENT OF ENERGY}

J. D. Darby, DOE-EM

J. P. Donnelly, DOE-NNSA

TENNESSEE DEPARTMENT OF

ENVIRONMENT AND CONSERVATION

DOE-ORR OVERSIGHT DIVISION

J. E. Sebastian

J. A. Owsley

B\&W Y-12, LLC PROGRAM MANAGEMENT

D. R. McDaniel

B\&W Y-12, LLC ENVIRONMENTAL COMPLIANCE DEPT.

V. J. Brumback

T. K. Cothron

S. M. Field

C. C. Hill

S. B. Jones

E. R. Schultz

S. E. McNamara

L. O. Vaughan

B\&W Y-12, LLC

ANALYTICAL CHEMISTRY ORGANIZATION

L. K. Rawlins

B\&W Y-12, LLC

ENGINEERING ORGANIZATION

S. B. Ahmed

S. A. Shults

Y-12 Central Files

9114DMC-01971865.6551-RC

Y-12 Records Services (Electronic copy- OSTI)

YDCC - RC $\underline{\text { URS }}$ | CH2M OAK RIDGE LLC

M. E. Cleveland (RSI)

H. K. Haase

R. H. Ketelle (RSI)

J. W. Kubarewicz

L. M. Sims (RSI)

File - EMEF-DMC

File - Y-12 Project PDCC

SCIENCE APPLICATIONS

INTERNATIONAL CORPORATION

W. K. Jago

UT-BATTELLE, LLC

D. B. Watson

$\underline{\text { ELVADO ENVIRONMENTAL LLC }}$

T. R. Harrison

J. R. Walker 
